OAK RIDGE

ORNL/TM-2003/226

NATIONAL LABORATORY

MANAGED BY UT-BATTELLE

FOR THE DEPARTMENT OF ENERGY

\title{
An Assessment of the Bioaccumulation of PCBs and Chlordane Near the U.S. Department of Energy's Kansas City Plant
}

M. J. Peterson

G. R. Southworth

J. M. Loar

September 2003
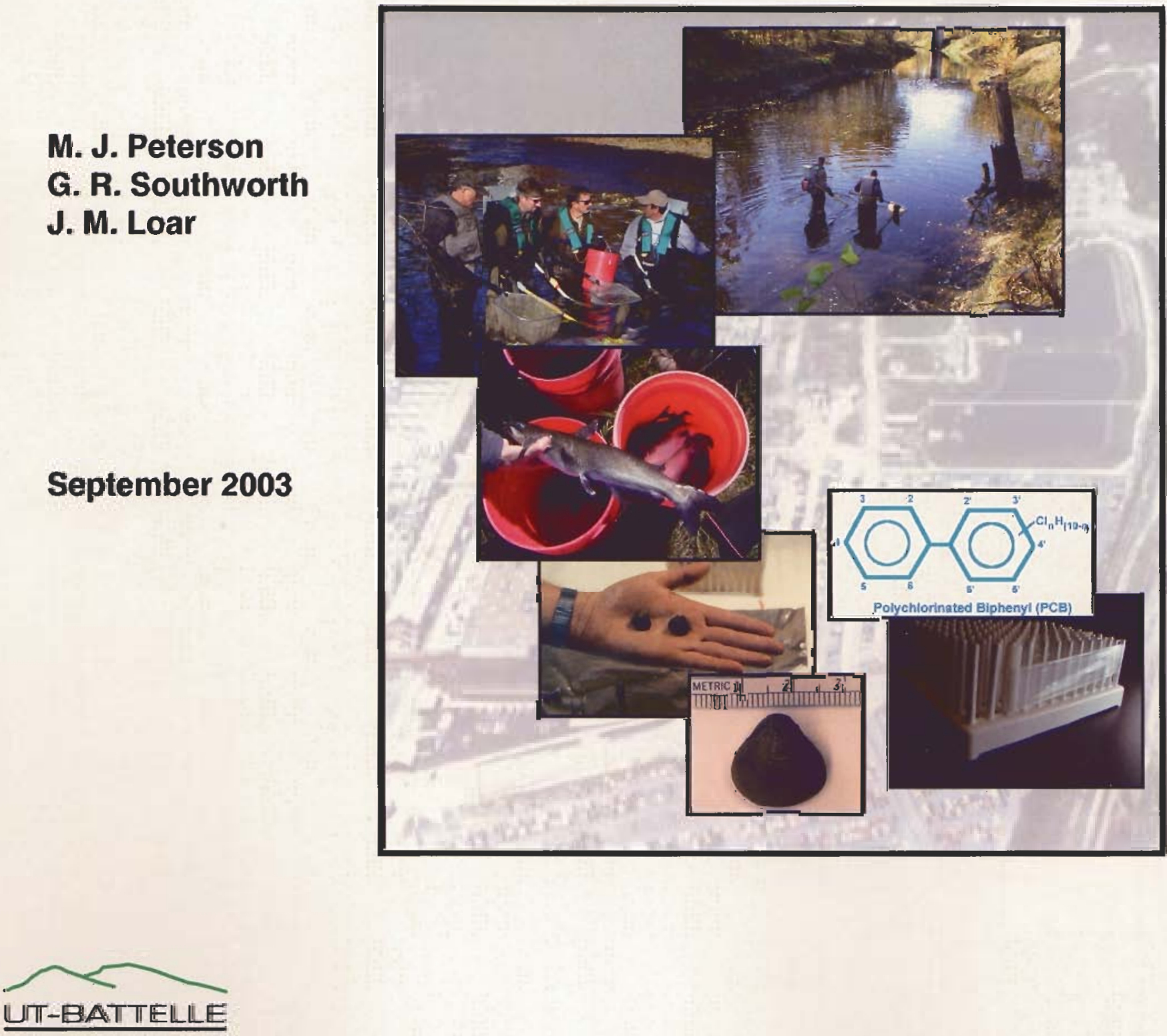


\section{DOCUMENT AVAILABILITY}

Reports produced after January 1, 1996, are generally available free via the U.S. Department of Energy (DOE) Information Bridge.

Web site http://www.osti.gov/bridge

Reports produced before January 1, 1996, may be purchased by members of the public from the following source.

National Technical Information Service

5285 Port Royal Road

Springfield, VA 22161

Telephone 703-605-6000 (1-800-553-6847)

TDD 703-487-4639

Fax 703-605-6900

E-mail info@ntis.fedworld.gov

Web site http://www.ntis.gov/support/ordernowabout.htm

Reports are available to DOE employees, DOE contractors, Energy Technology Data

Exchange (ETDE) representatives, and International Nuclear Information System (INIS)

representatives from the following source.

Office of Scientific and Technical Information

P.O. Box 62

Oak Ridge, TN 37831

Telephone 865-576-8401

Fax 865-576-5728

E-mail reports@adonis.osti.gov

Web site http://www.osti.gov/contact.html

This report was prepared as an account of work sponsored by an agency of the United States Government. Neither the United States Government nor any agency thereof, nor any of their employees, makes any warranty, express or implied, or assumes any legal liability or responsibility for the accuracy, completeness, or usefulness of any information, apparatus, product, or process disclosed, or represents that its use would not infringe privately owned rights. Reference herein to any specific commercial product, process, or service by trade name, trademark, manufacturer, or otherwise, does not necessarily constitute or imply its endorsement, recommendation, or favoring by the United States Government or any agency thereof. The views and opinions of authors expressed herein do not necessarily state or reflect those of the United States Government or any agency thereof. 
Environmental Sciences Division

\title{
AN ASSESSMENT OF THE BIOACCUMULATION OF PCBS AND CHLORDANE NEAR THE U.S. DEPARTMENT OF ENERGY'S KANSAS CITY PLANT
}

\author{
Mark J. Peterson \\ George R. Southworth \\ James M. Loar \\ Environmental Sciences Division \\ Oak Ridge National Laboratory
}

Date Published: September 2003

Prepared for:

U.S. Department of Energy

Kansas City Plant

2000 East 95th Street

Kansas City, MO 64141-6159

OAK RIDGE NATIONAL LABORATORY

Oak Ridge, Tennessee 37831-6036

managed by

UT-BATTELLE, LLC

for the

U.S. DEPARTMENT OF ENERGY

under contract DE-AC05-00OR22725 



\section{CONTENTS}

LIST OF FIGURES............................................................................................................................. VII

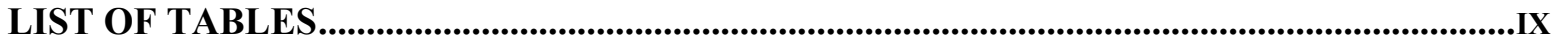

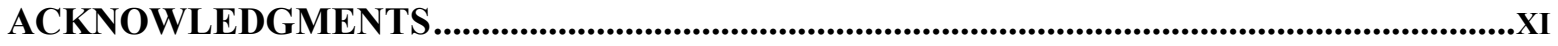

1. INTRODUCTION .................................................................................................................................... 1

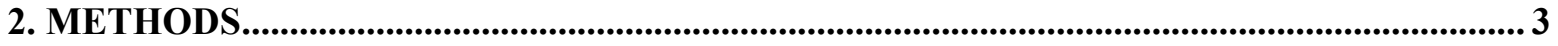

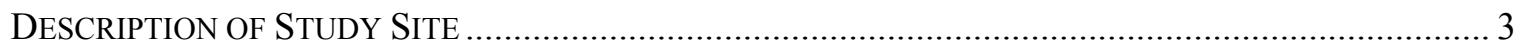

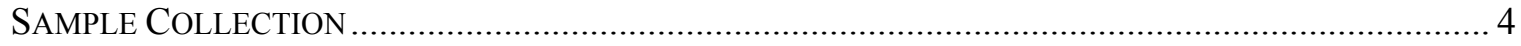

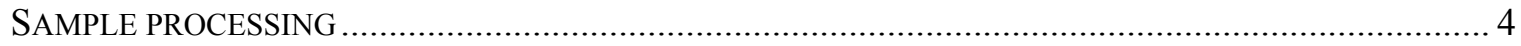

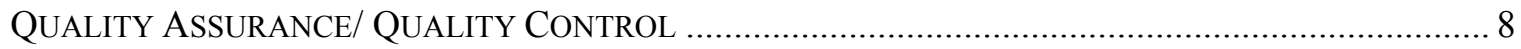

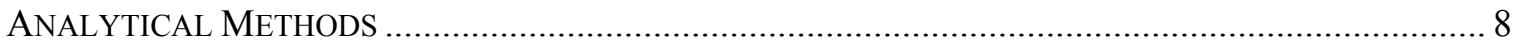

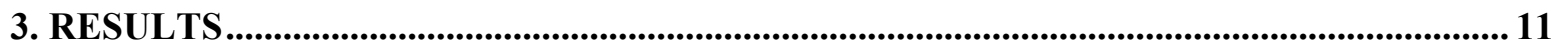

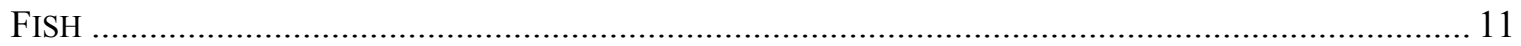

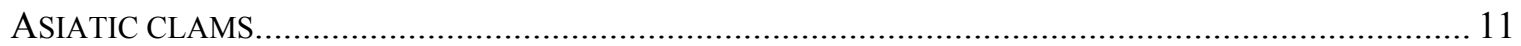

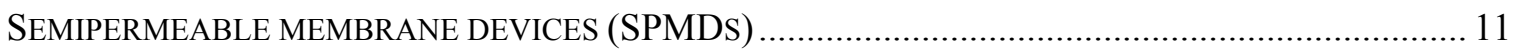

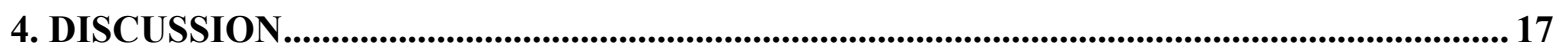

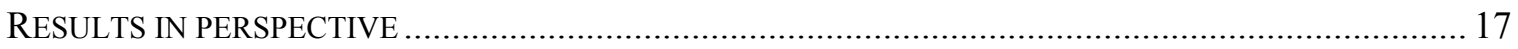

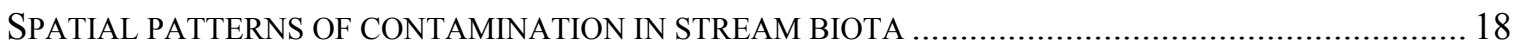

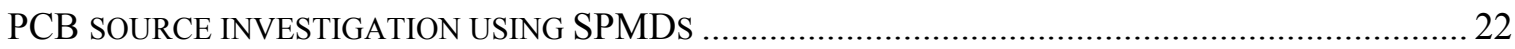

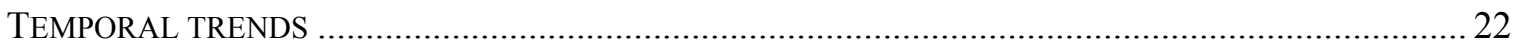

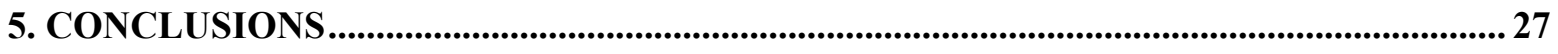

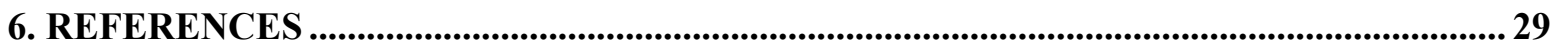

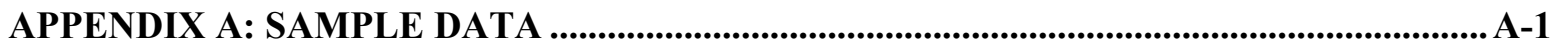

APPENDIX B: QUALITY ASSURANCE SUMMARY ........................................................ B-1 



\section{LIST OF FIGURES}

Figure

Page

1 Location of the Kansas City Plant in relation to local waters and major roads...

2 Stream sampling locations for fish and clams, and approximate locations of major KCP outfalls entering Indian Creek and the Blue River

3 In-plant SPMD sampling locations that feed into outfall 002,

November 2002 and March 2003

4 Schematic showing spatial pattern of Aroclor 1242 in sunfish and SPMDs near and within the Kansas City Plant as a result of the present study

$5 \quad$ Schematic showing spatial pattern of higher chlorinated Aroclors (Aroclor $1254+1260$ ) in green sunfish collected near the Kansas City Plant, November 2002

6 Schematic showing spatial distribution of mean total PCB concentrations in three species collected near KCP in November, 2002: green sunfish, Asiatic clams, and channel catfish

7 Mean PCB concentrations in Indian Creek green sunfish in 2002

relative to mean values found in previous sampling years

8 Mean PCB concentrations in Blue River green sunfish in 2002

relative to mean values found in previous sampling years

9 Mean PCB concentrations in Boone Creek green sunfish in 2002 relative to mean values found in previous sampling years

10 Mean PCB concentrations in channel catfish over time

11 Mean chlordane concentrations in channel catfish over time 



\section{LIST OF TABLES}

Table

Page

1 Sample collection information for PCB monitoring near and within the Kansas City Plant in October - November 2002, and an SPMD deployment in February - March, 2003

2 Mean PCB concentrations $(\mu \mathrm{g} / \mathrm{g}, \pm \mathrm{SD}$ ) in green sunfish (Lepomis cyanellus) in streams near the Kansas City Plant, October - November 2002

3 Mean PCB concentrations ( $\mu \mathrm{g} / \mathrm{g}, \pm \mathrm{SD}$ ) in channel catfish (Ictalurus punctatus) in streams near the Kansas City Plant, November 2002

4 Mean chlordane concentrations $(\mu \mathrm{g} / \mathrm{g}, \pm \mathrm{SD})$ in channel catfish (Ictalurus punctatus) in streams near the Kansas City Plant, November 2002

5 Mean PCB concentrations ( $\mu \mathrm{g} / \mathrm{g}, \pm \mathrm{SD}$ ) in Asiatic clams (Corbicula fluminea) collected from streams near the Kansas City Plant, November 2002

6 Mean PCB concentrations $(\mu \mathrm{g} / \mathrm{g}, \pm \mathrm{SD}$; outfalls) in triolein oil from semipermeable membrane devices (SPMDs) placed in storm drains and stream discharges, October 28 - November 25, 2002.

$7 \quad$ Mean PCB concentrations $(\mu \mathrm{g} / \mathrm{g})$ in triolein oil from semipermeable membrane devices (SPMDs) placed in storm drains, February 18/20 - March 13, 2003 



\section{ACKNOWLEDGMENTS}

This study was funded by the Department of Energy's Kansas City Plant and Honeywell FM\&T. Special thanks are extended to Mike Stites for his guidance and support on this project. We would also like to thank Jim Tucholski and Bob Bitter, both of the Kansas City Plant, for their assistance in the field.

Thanks are also extended to Rick Zingg of the Y-12 BWXT Analytical Services Organization for analytical support. 



\section{INTRODUCTION}

Studies conducted by the Missouri Department of Conservation in the late 1980s found high levels of PCBs and chlordane in fish from the Blue River near the Kansas City Plant (KCP). Follow-on biomonitoring studies by Oak Ridge National Laboratory (ORNL) staff from 1991-1993 (Southworth et al. 1992, Ashwood et al. 1993, Ashwood and Peterson 1994), and again on a more limited basis in 1998 (Ashwood 1998), were conducted for the KCP. The studies in the early 1990s characterized concentrations of PCBs and chlordane in fish from Indian Creek, Boone Creek, and the Blue River. These studies concluded that the KCP appears to be one of multiple sources of PCBs to both Indian Creek and the Blue River.

There continues to be interest in the potential role of KCP discharges on PCB concentrations in local fish. Elevated PCB concentrations in Indian Creek fish have consistently been found at the location downstream of the NPDES-permitted 002 discharge, which drains a section of the KCP complex. A risk evaluation conducted during 2001 found that some local fish exceeded risk-based guidelines for PCBs. It has been nearly a decade since intensive sampling of fish was conducted within all waters near the KCP (the 1998 study included Indian Creek only); therefore, an update study was warranted.

The purpose of the present study is to provide PCB and chlordane concentrations in fish useful in determining the potential human health risks associated with fish in waters near the KCP, to evaluate the relative significance of $\mathrm{KCP}$ discharges relative to other inputs on fish levels, and to determine if levels have changed in the years since fish were last analyzed. Fish were collected near the KCP for PCB and chlordane analyses in October and November of 2002. Although chlordane does not appear to be associated with the KCP (it was most commonly used to treat household termite infestations until 1988), it is of interest from an overall risk standpoint. Because monitoring change over time is an important component of this effort, the fish sampling locations and species collected were essentially the same as in previous studies. In general, locations were chosen upstream and downstream of major KCP outfalls to help evaluate the importance of those outfalls as sources of PCBs. Green sunfish (Lepomis cyanellus) and channel catfish (Ictalurus punctatus) were again the primary species collected.

In addition to fish, resident Asiatic clams were collected for PCB analysis from the same sites (with the exception of Boone Creek where they were not present). Clams are lipid-rich, immobile organisms that effectively accumulate organic compounds. The monitoring of clams offers additional assurance that fish movement/migration does not strongly influence the PCB concentrations observed in fish. In an effort to identify KCP-specific sources of PCBs, Semi-permeable Membrane Devices (SPMDs) were placed at select locations within the KCP storm drain network. SPMDs are lipid-filled bags that have been likened to a "mechanical clam"; they are advantageous because they can provide a measure of PCB exposure in environments where no clams or other biota are present (Huckins et al., 1992).

The concurrent monitoring of a variety of biotic and abiotic media in 2002 provides the most comprehensive picture yet of the role of the KCP on PCB bioaccumulation in Indian Creek and the Blue River. 



\section{METHODS}

\section{Description of Study Site}

The Kansas City Plant (KCP) is a part of the Bannister Federal Complex located in a commercial and residential area $\sim 13$ miles south of downtown Kansas City, Missouri, within the incorporated city limits. The KCP occupies 137 of the 300 acres covered by the complex. The nearby Blue River and its tributaries, Indian Creek and Boone Creek, receive surface water runoff, discharges permitted under the National Pollutant Discharge Elimination System (NPDES), and groundwater from the federal complex (Fig. 1).

Indian Creek and the Blue River also receive runoff from residential and commercial facilities, and discharges from sewage treatment plants upstream from the KCP. In general, the biological communities of lower Indian Creek and the Blue River below its confluence with Indian Creek are negatively impacted by a number of factors, including industrial and sewage treatment discharges, urban-parking lot runoff, intermittent spills, bank erosion and siltation, excessive sedimentation, and stream channelization. Water quality is relatively good in the Blue River above the confluence with Indian Creek, but a large sewage treatment plant on Indian Creek degrades water quality in the lower half of the river (Petchford et al. 1999). Like many urban streams, the system is flashy (i.e., rapidly rising and falling stream flows), and the extreme flow changes can also adversely affect resident aquatic biota.

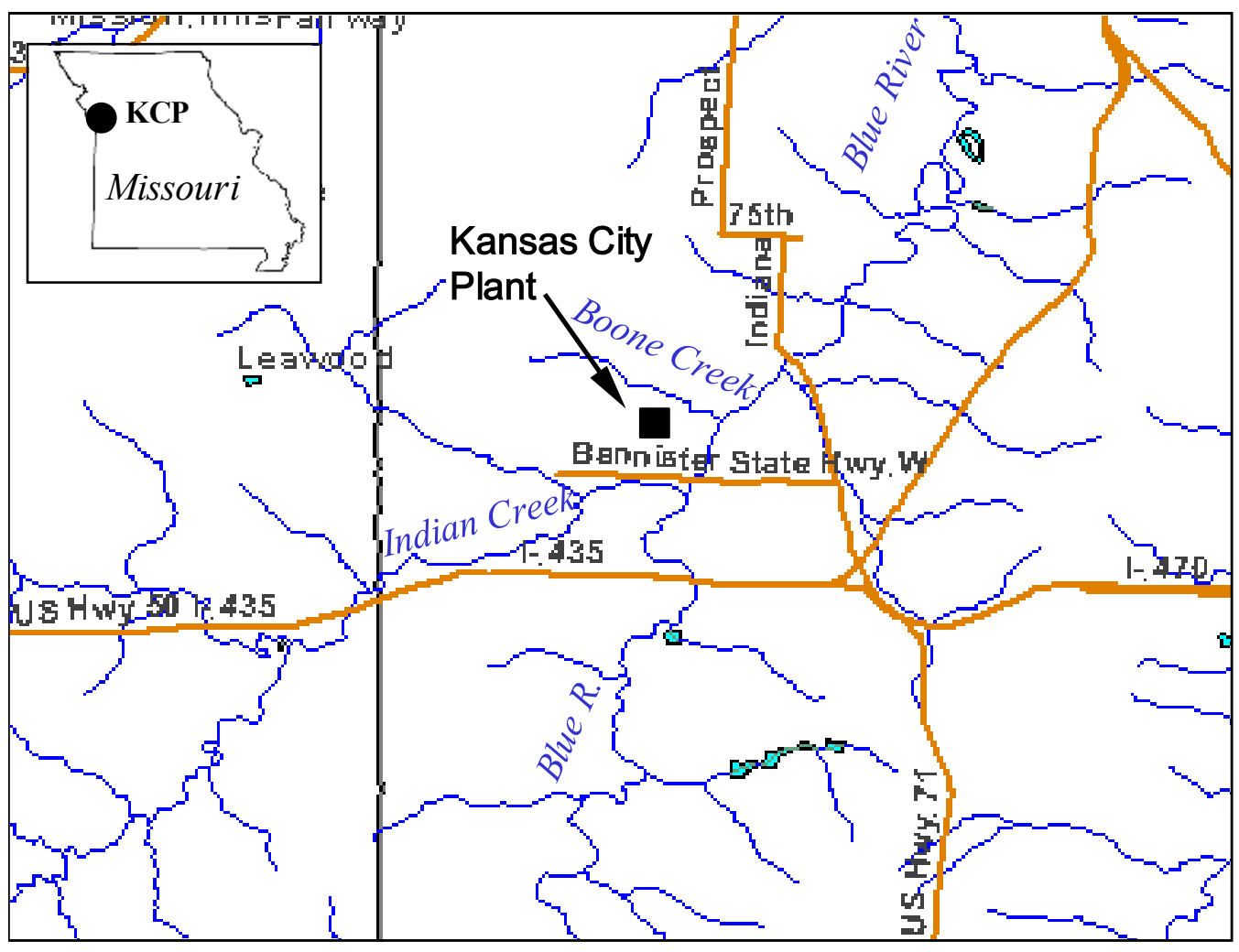

Fig. 1. Location of the Kansas City Plant in relation to local waters and major roads. 


\section{Sample Collection}

The Blue River can be difficult to sample under any flow conditions but is particularly difficult when flows are high. For this reason the fall period, when flows on average are lowest, was targeted for the fish collection effort. Sampling was initiated on October 28, 2002, but due to increased flow conditions during that period, only Boone Creek could be safely sampled. Deployment of SPMDs was possible, however, and SPMDs were placed at outfall and storm drain sites on October 28 and 29 for a four-week deployment. Fish and clam collection activities in Indian Creek and the Blue River resumed November 12 - 15, 2002 when flows had decreased. Over a threeday period all stream sites were sampled and the fish and clam collection was completed. The SPMDs were removed on November 25. A follow-up deployment of SPMDs was conducted at additional sites over the February 18/20 - March 13, 2003 period.

Green sunfish were the primary species targeted by previous monitoring programs at KCP, and were again targeted for the present study. Green sunfish are an ideally suited fish species for evaluating the importance of KCP discharges, because they are locally abundant, short-lived, and relatively sedentary, providing a recent measure of PCB exposure at the site of collection. Sunfish, however, are low-lipid, short-lived fish that are not representative of the maximum concentrations likely to occur in an aquatic system. Near the KCP, channel catfish are a good indicator of the maximum concentrations likely to be present in fish, because they are at the top of the food chain, have high intramuscular lipids, and reach an older age than sunfish.

The fish were collected by backpack electrofishing. Seven sites [3 sites on Indian Creek (ICK 3.0, ICK 1.0, ICK 0.2), one site on Boone Creek (BCK 0.2), and 3 sites on the Blue River (BLK 31, BLK 27, BLK 25)] were sampled as in the 1993 study (Ashwood and Peterson, 1994) (Fig. 2). The numbered designation refers to the kilometer distance upstream of the stream mouth. The sites are located upstream and downstream of the major KCP discharges to Indian Creek and the Blue River. Each green sunfish filet was analyzed for PCBs only, as chlordane has been shown in previous studies to be at or near background levels in sunfish. Channel catfish ( 8 individuals per site) were collected from one site in Indian Creek, and two sites in the Blue River (one above and one below the confluence with Indian Creek). One individual catfish collected from Boone Creek and one from BLK 25.0 were also kept and analyzed. Channel catfish were analyzed for both PCBs and chlordane. In some cases, a large reach needed to be sampled to collect the necessary fish.

Asiatic clams were collected from the same sites as sunfish in Indian Creek and the Blue River. No clams were found in Boone Creek. The clams were collected by dipnet. Approximately 50-100 clams were obtained at each site, with the exception of ICK 3.0 where only 28 clams were obtained. At ICK 0.2 it was extremely difficult to find clams, but eventually enough individuals were collected from one small area of the stream.

SPMDs were deployed near outfall discharge points and in storm drains (Fig 3). In-plant locations were chosen based on accessibility and prior knowledge of potential PCB sources in the plant. The November 2002 sampling focused on permitted outfalls $(001,002$, and 003/004) and sites within the trunk line of the storm drain system leading to outfall 002. The March 2003 deployment investigated PCBs in the lateral drains feeding the 002 trunk line.

A summary of the sample collection information for all media is provided in Table 1.

\section{Sample processing}

Retained fish were individually identified with a unique four-digit tag wired to the lower jaw and placed in a cooler on ice immediately after collection. Sunfish greater than 40 grams in size and channel catfish greater than 400 grams in size were targeted, in order to minimize possible bias related to size/contaminant covariance and to provide a direct measure of risks to sport fishermen. Average sunfish weight per site in Indian Creek and the Blue River ranged as low as 40.4 grams at ICK 3.0 and as high as 51.8 grams at BLK 27.0. By necessity, a smaller-sized group of fish (average 


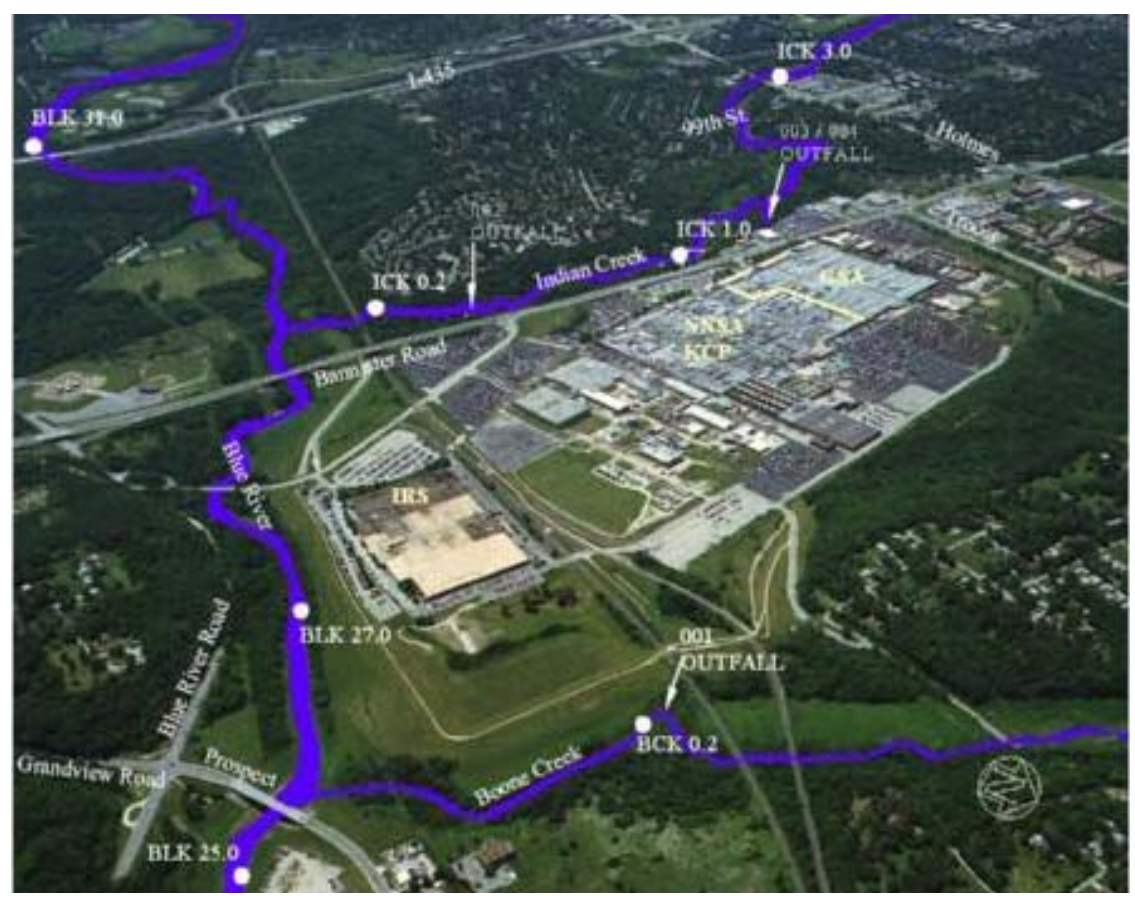

Fig. 2. Stream sampling locations for fish and clams, and approximate locations of major KCP outfalls entering Indian Creek and the Blue River.

weight 29.1 grams) was collected from Boone Creek where suitable habitat for sunfish was limited.

Processing of the fish was initiated within 48 hours of collection. Each fish was weighed, measured to obtain total length, sexed, and examined for any superficial abnormalities. The fish was then scaled, and the filet with skin removed. A 5-gram subsample was exised from the filet, wrapped in heavy-duty aluminum foil, labeled, and placed on dry ice. Any remaining filet was similarly wrapped, labeled, frozen, and archived for possible future use. The entire catfish filet, with skin removed, was obtained for future homogenization at the ORNL Fish Processing Laboratory (FPL). All fish samples were kept in a cooler with dry ice until delivery to the ORNL FPL, where they were stored in a freezer at $-20^{\circ} \mathrm{C}$ prior to submission to the analytical lab. Field and laboratory sample data for individual fish is provided in Appendix A.

Clams were collected by dip net, wrapped in aluminum foil labeled with the site and date of collection, and placed on dry ice. At the laboratory, the clams were sorted into two batches of 20 similarly-sized individuals, weighed, and the soft tissue removed for PCB analysis (Appendix A). At ICK 3.0 the composite samples consisted of one 8-clam sample of good representative-sized clams, and one 20-clam sample of very small clams.

Semipermeable membrane devices were prepared using low-density polyethylene lay-flat tubing (160 cm long, $2.6 \mathrm{~cm}$ wide, by $0.05 \mathrm{~mm}$ thick). Tubing was cleaned in hexane for 48 hours prior to construction of the SPMDs. Each tube was heat sealed in the middle. One milliliter of triolein oil (95\% purity, Sigma Aldrich, Inc) was pipetted into each compartment of the tubing and spread into a thin layer coating the entire inside of the tubing, after which the tube was heat-sealed at both ends. 


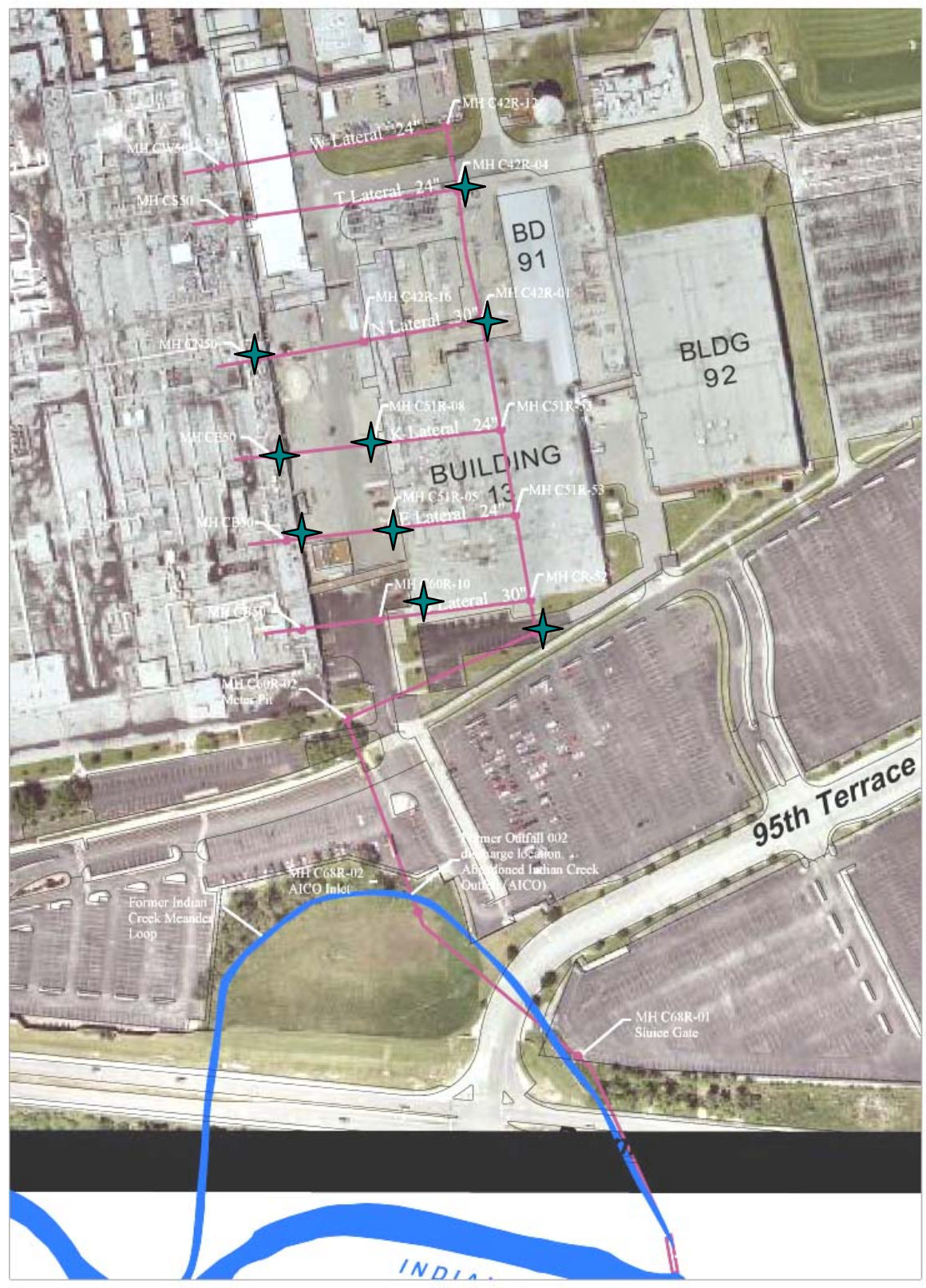

Fig. 3. In-plant SPMD sampling locations that feed into outfall 002, November 2002 and March 2003. 
Table 1. Sample collection information for $\mathrm{PCB}$ monitoring near and within the Kansas City Plant in October - November 2002, and an SPMD deployment in February - March, 2003. Values represent the number of individuals collected

\begin{tabular}{|c|c|c|c|c|}
\hline \multirow[b]{2}{*}{ Site } & \multicolumn{3}{|c|}{ Species } & \multirow[b]{2}{*}{ SPMD $^{b}$} \\
\hline & Green sunfish & Channel catfish & Asiatic clam $^{\mathrm{a}}$ & \\
\hline \multicolumn{5}{|l|}{ Indian Creek } \\
\hline ICK 3.0 & 8 & & $\mathrm{X}$ & \\
\hline ICK 1.0 & 8 & & $\mathrm{X}$ & $X(003 / 004)$ \\
\hline ICK 0.2 & 8 & 8 & $\mathrm{X}$ & X (002) \\
\hline \multicolumn{5}{|l|}{ Boone Creek } \\
\hline BCK 0.2 & 8 & 1 & & $X(001)$ \\
\hline \multicolumn{5}{|l|}{ Blue River } \\
\hline BLK 31.0 & 8 & 8 & $\mathrm{X}$ & \\
\hline BLK 27.0 & 8 & 8 & $\mathrm{X}$ & \\
\hline BLK 25.0 & 8 & 1 & $\mathrm{X}$ & \\
\hline \multicolumn{5}{|c|}{ KCP Storm drain sites } \\
\hline Junction box $\mathrm{N}$ & & & & $X$ \\
\hline Junction box $\mathrm{T}$ & & & & $\mathrm{X}$ \\
\hline B lateral & & & & $X$ \\
\hline E lateral & & & & $\mathrm{X}$ \\
\hline K lateral & & & & $\mathrm{X}$ \\
\hline E $501 / 2$ & & & & $X$ \\
\hline K 501/2 & & & & $X$ \\
\hline N 501/2 & & & & $X$ \\
\hline 002 Dogleg & & & & $\mathrm{X}$ \\
\hline Duplicates & 5 & 3 & 6 & \\
\hline Total Samples & 61 & 29 & 12 & \\
\hline
\end{tabular}

${ }^{\mathrm{a}}$ At least 20 clams were collected from each site.

${ }^{\mathrm{b}}$ SPMDs placed at sites on 10/28/02 and collected on 11/25/02. Lateral and 501/2 sites were sampled by SPMDs over the February 18/20 - March 13, 2003 period.

The SPMD tubes were then wrapped in 10 parallel rows on a $16 \mathrm{~cm} \times 11 \mathrm{~cm}$ polypropylene test tube drying rack. Two such units were then enclosed in an aluminum cage to protect the SPMDs from debri and abrasion, and emplaced at sites in the drainage system near and within the Kansas City Plant. In the second deployment, which targeted smaller pipes within the storm drain network, SPMDs were deployed as a ribbon strung in the current because the protective cages were too bulky to fit into those locations. After retrieval, the SPMDs were removed from their protective cages, and wiped with a moistened towel to remove surface film. The corner was cut from one compartment of an SPMD, and the triolein oil was carefully squeezed into a pre-cleaned (I-Chem, Inc) glass vial and sent to the laboratory for analysis. 


\section{Quality Assurance/ Quality Control}

Fish, clam, and SPMD samples were collected and processed according to project-specific standardized technical procedures developed by the ORNL Biological Monitoring and Abatement Program (BMAP) to ensure quality and integrity. Chain-of-custody documentation followed the samples from collection to submission to the analytical laboratory. BMAP quality assurance procedures are consistent with EPA recommendations for assessing chemical contaminant data for use in fish advisories (EPA 1995).

A summary of the quality assurance/quality control data from the analytical laboratory is provided in Appendix A. The quality of the analytical data was evaluated by a combination of blind duplicate analyses, analysis of uncontaminated fish, and determination of recoveries of analyte spikes. Standard quality control information (e.g., method holding times, method blank results, and calibration checks) was obtained by the analytical laboratory during the sample runs and this information was provided to ORNL staff. The analytical data was reviewed and deemed acceptable for its intended use.

\section{Analytical Methods}

Conventional capillary column gas chromatography was used to quantify PCBs (all detected Aroclors) and alpha and gamma chlordane. The BWXT Analytical Chemistry Organization analyzed all samples, including fish, clams, and SPMD oils. This laboratory has analyzed PCBs for ORNL staff since 1985, and there is a high degree of confidence in the reported results.

Samples were prepared by Soxhlet Extraction - SW846 Method 3540B. The extracts were analyzed by SW846 Method 8082 entitled Polychlorinated Biphenyls (PCBs) by Gas Chromatography (EPA 1986). The instrumentation utilized was a Hewlett Packard model 5890 (GCGC2) gas chromatograph. The instrument was configured using dual capillary columns, with the more sensitive Resteck Rtx-1701chosen as the primary column. The second column results were considered confirmational data. Following dilution in hexane and Florisil cleanup, detection was accomplished using dual electron capture detectors (GC/ECD).

For routine capillary column analyses, results are reported with a variety of qualifiers that can be confusing to people unfamiliar with processing analytical data. Results with qualifiers are presented in a number of the tables in this report. Common value qualifiers presented in this study's datasets include: "U", "J", and "P". For any reported value without a qualifier there is reasonable confidence in the quantitation of the reported result. Undetected results that are below the contract required quantitation limit are flagged with a "U". For each value flagged with a "U", there is a corresponding lower limit, or method detection limit, reported by the analytical laboratory. This is the absolute detection limit and no quantitation of the contaminant is provided by the laboratory below this value. For the undetected Aroclors reported for this study, on average there was an approximate 5-fold difference between the lower limit and the quantitation limit. Values designated with a "J" are estimated values, representing a result that was detected above the lower limit, but below the quantitation limit. As with most studies, values qualified with a "J" were used in the summary calculations herein. A "P" designates that there was greater than a $25 \%$ difference in the two column results. A "P" designation may not designate a quality control issue when results are extremely low and there is a small absolute difference between column results.

Considerable effort was made to obtain low detection limits for this study. Important factors that influence the detection limit is sample size and instrument limits. Analytical detection limits for this study were deemed excellent given the difficulty in obtaining the optimum sample size for the sunfish samples; the average lower limit for all Aroclors $(\mathrm{n}=553)$ was $0.01 \mu \mathrm{g} / \mathrm{g}$ and the average quantitation limit was $0.05 \mu \mathrm{g} / \mathrm{g}$. The lowest reported PCB detection limit was $0.002 \mu \mathrm{g} / \mathrm{g}$.

The SPMD results provide a time-integrated, semi-quantitative index of the mean 
concentration of the desired analyte in the overlying water over the course of their deployment. (McCarthy et al. 2000). If careful calibration in laboratory studies is carried out in conjunction with field deployments, results of such monitoring can be used to provide fairly accurate estimates of aqueous concentrations. However, for more routine screening applications (as was the case in this study) where water velocity and temperature are not monitored and careful attention to clogging and obstruction are not employed, the results cannot be used to measure aqueous concentrations. The SPMD results in this study do provide an indication of the relative importance of various sources within the plant. 



\section{RESULTS}

Mean PCB and/or chlordane concentrations ( \pm standard deviation) are provided in the following summary tables for fish, clams, and SPMDs at each site. Individual fish and clam data is provided in Appendix A.

At sites with a higher number of nondetects, mean concentrations are highly dependent upon how detection limit values are used in the calculations. For these tables, the lower limit was used in calculating each Aroclor mean, and the mean is footnoted when more than half the values used were below detection. To calculate the mean total PCB concentration for the site, the total PCB value for each sample was calculated by summing the detected Aroclors; in cases where all Aroclors were nondetects, the highest Aroclor-specific nondetect was used to represent the total PCBs for that sample. Consequently, the mean total PCB values presented in the tables may differ slightly from the addition of Aroclor-specific averages.

Values that are estimated (i.e., with J qualifiers) or those with a greater than $25 \%$ difference between analytical columns (i.e., with P qualifiers) were used to calculate the mean values presented in the tables. Aroclor 1254 and 1260 results are combined because of the difficulty in distinquishing separate peaks for these Aroclors on the chromatograms (only one or the other was detected).

\section{Fish}

In general, PCB concentrations in sunfish and channel catfish near the Kansas City Plant (KCP) were low, with many samples having PCB concentrations at or near detection limits (Tables 2 and 3). Higher PCB concentrations were found in fish downstream of KCP discharges, but PCBs were also detected in fish collected upstream of the plant. The highest PCB concentrations in sunfish were found in fish from Boone Creek, while the highest PCB concentrations in catfish were found in fish from the Blue River (BLK 27.0). Lower chlorinated PCB mixtures (Aroclor 1242) were found in both species only at sites downstream of the KCP outfalls. In contrast, the more highly chlorinated mixtures (Aroclor 1254 and Aroclor 1260) were found in fish and clams both upstream and downstream of KCP discharges. The following Aroclors were not detected in any KCP sample: Aroclor 1016, 1221, 1232, and 1248.

Low alpha and gamma chlordane concentrations were found in catfish from all sites, both upstream and downstream of KCP discharges (Table 4).

\section{Asiatic clams}

Very low PCB concentrations were detected in Asiatic clams and only from sites in the Blue River (Table 5). No PCBs were detected in clams collected from the three sites in Indian Creek. Like fish, higher chlorinated PCBs were found in clams upstream of KCP discharges, while PCB-1242 was only detected in the clams detected downstream of KCP.

\section{Semipermeable membrane devices (SPMDs)}

Extracts of low-chlorinated PCBs resembling Aroclor 1242 (identified as Aroclor 1248 in March 2003) were found in SPMDs at all sites where they were placed in the storm drain network feeding Outfall 002 (Tables 6 and 7; Fig. 3). 
Table 2. Mean PCB concentrations $(\mu \mathrm{g} / \mathrm{g}, \pm \mathrm{SD})$ in green sunfish (Lepomis cyanellus) in streams near the Kansas City Plant, October - November 2002. N=8 individual fish collected from each site

\begin{tabular}{lccc}
\hline & \multicolumn{3}{c}{ PCBs } \\
\cline { 2 - 4 } Site & $\begin{array}{c}\text { Aroclor- } \\
1242^{-}\end{array}$ & $\begin{array}{c}\text { Aroclor- } \\
1254 \text { or 1260 }\end{array}$ & Total \\
\hline Indian Creek & $<0.03^{\mathrm{a}}$ & $0.02 \pm 0.01^{\mathrm{b}}$ & $0.02 \pm 0.01$ \\
ICK 3.0 & $0.04 \pm 0.04^{\mathrm{c}}$ & $0.04 \pm 0.03^{\mathrm{b}}$ & $0.06 \pm 0.06$ \\
ICK 1.0 & $0.06 \pm 0.08^{\mathrm{d}}$ & $0.04 \pm 0.04^{\mathrm{d}}$ & $0.09 \pm 0.12$ \\
ICK 0.2 & & & \\
& & & $0.39 \pm 0.08$ \\
Boone Creek & $0.23 \pm 0.06$ & $0.16 \pm 0.04$ & \\
BCK 0.2 & & & $<0.03^{\mathrm{a}}$ \\
Blue River & $<0.03^{\mathrm{a}}$ & $<0.03^{\mathrm{a}}$ & $0.02^{\mathrm{a}}$ \\
BLK 31.0 & $0.02^{\mathrm{a}}$ & $0.02^{\mathrm{a}}$ & $0.06 \pm 0.05$ \\
BLK 27.0 & $0.04 \pm 0.02$ & $0.03 \pm 0.03$ & \\
BLK 25.0 & & &
\end{tabular}

\footnotetext{
${ }^{a}$ Maximum nondetected value reported of 8 fish analyzed.

b 6 of 8 samples below detection limit.

${ }^{\mathrm{c}} 7$ of 8 samples below detection limit.

$\mathrm{d} 5$ of 8 samples below detection limit.
}

Table 3. Mean PCB concentrations ( $\mu \mathrm{g} / \mathrm{g}, \pm \mathrm{SD}$ ) in channel catfish (Ictalurus punctatus) in streams near the Kansas City Plant, November 2002. $\mathrm{N}=8$ except at BCK 0.2 and BLK 25.0, where $\mathrm{N}=1$.

\begin{tabular}{lccc}
\hline \multirow{2}{*}{ Site } & \multicolumn{3}{c}{ PCBs } \\
\cline { 2 - 4 } & $\begin{array}{c}\text { Aroclor- } \\
1242\end{array}$ & $\begin{array}{c}\text { Aroclor- } \\
1254 \text { or 1260 }\end{array}$ & Total \\
\hline $\begin{array}{l}\text { Indian Creek } \\
\text { ICK 0.2 }\end{array}$ & $0.03 \pm 0.02$ & $0.05 \pm 0.01$ & $0.07 \pm 0.02$ \\
Boone Creek & & & \\
BCK 0.2 & 0.02 & 0.15 & 0.17 \\
Blue River & & & \\
BLK 31.0 & $<0.007$ & $0.03 \pm 0.01$ & $0.03 \pm 0.01$ \\
BLK 27.0 & $0.07 \pm 0.09$ & $0.18 \pm 0.04$ & $0.24 \pm 0.12$ \\
BLK 25.0 & 0.02 & & 0.05 \\
\hline
\end{tabular}


Table 4. Mean chlordane concentrations $(\mu \mathrm{g} / \mathrm{g}, \pm \mathrm{SD})$ in channel catfish (Ictalurus punctatus) in streams near the Kansas City Plant, November 2002. N=8 except at BCK 0.2 and BLK 25.0, where $\mathrm{N}=1$. Sum totals are the addition of alpha and gamma chlordane, but do not rule out the presence of other chlordane isomers.

\begin{tabular}{lccc}
\hline & \multicolumn{3}{c}{ Chlordane } \\
\cline { 2 - 4 } Site & Alpha & Gamma & Sum \\
\hline Indian Creek & $0.01 \pm 0.01$ & $0.01 \pm 0.01$ & $0.02 \pm 0.01$ \\
ICK 0.2 & & & \\
Boone Creek & 0.01 & $<0.0007$ & 0.01 \\
BCK 0.2 & & & \\
Blue River & $0.003 \pm 0.001$ & $0.001 \pm 0.001^{\mathrm{a}}$ & $0.004 \pm 0.002$ \\
BLK 31.0 & $0.01 \pm 0.01$ & $0.004 \pm 0.009^{\mathrm{a}}$ & $0.02 \pm 0.02$ \\
BLK 27.0 & 0.002 & $<0.0003$ & 0.002 \\
BLK 25.0 & & & \\
\end{tabular}

${ }^{\mathrm{a}} 7$ of 8 samples below detection limit.

Table 5. Mean PCB concentrations ( $\mu \mathrm{g} / \mathrm{g}, \pm \mathrm{SD}$ ) in Asiatic clams (Corbicula fluminea) collected from streams near the Kansas City Plant, November 2002. At least 20 clams were collected from each site; $\mathrm{N}=2$ composite samples of clams per site.

\begin{tabular}{lccc}
\hline \multirow{2}{*}{ Site } & \multicolumn{3}{c}{ PCBs } \\
\cline { 2 - 4 } & $\begin{array}{c}\text { Aroclor- } \\
\text { 1242 }\end{array}$ & $\begin{array}{c}\text { Aroclor- } \\
\text { 1254 or 1260 }\end{array}$ & Total \\
\hline Indian Creek & & & $<0.08$ \\
ICK 3.0 & $<0.04$ & $<0.04$ & $<0.007$ \\
ICK 1.0 & $<0.006$ & $<0.007$ & $<0.007$ \\
ICK 0.2 & $<0.006$ & $<0.007$ & \\
Blue River & & & $0.03 \pm 0.005$ \\
BLK 31.0 & $<0.01$ & $0.03 \pm 0.005$ & $0.06 \pm 0.004$ \\
BLK 27.0 & $0.03 \pm 0.003$ & $0.04 \pm 0.001$ & $0.08 \pm 0.01$ \\
BLK 25.0 & $0.04 \pm 0.004$ & $0.03 \pm 0.005$ & \\
\end{tabular}

At least 20 clams were collected from each site; $\mathrm{N}=2$ composite samples of clams per site. 
Table 6. Mean PCB concentrations $(\mu \mathrm{g} / \mathrm{g}, \pm \mathrm{SD} ; \mathrm{N}=2)$ in triolein oil from semipermeable membrane devices (SPMDs) placed in storm drains and outfalls, October 28 November 25, 2002

\begin{tabular}{lccc}
\hline \multirow{2}{*}{ Site } & \multicolumn{3}{c}{ PCBs } \\
\cline { 2 - 4 } & $\begin{array}{c}\text { Aroclor- } \\
1242\end{array}$ & $\begin{array}{c}\text { Aroclor- } \\
1254 \text { or 1260 }\end{array}$ & Total \\
\hline Indian Creek & $<0.1$ & $<0.2$ & $<0.2$ \\
ICK 1.0 (outfall 003/004) & $13 \pm 0$ & $<0.4$ & 13 \\
ICK 0.2 (outfall 002) & & & \\
Boone Creek & 0.7 & $<1.1$ & 0.7 \\
BCK 0.2 (outfall 001) & & & \\
KCP Storm drain sites & $108 \pm 31$ & $<2$ & 108 \\
Junction box N & $40 \pm 5$ & $<1$ & 40 \\
Junction box T & $31 \pm 9$ & $<0.6$ & 31 \\
002 Dogleg & & & \\
Reference stream: & & & \\
First Creek, ORNL & $<0.07$ & $<0.14$ & $<0.14$ \\
\hline
\end{tabular}

Table 7. Mean PCB concentrations ( $\mu \mathrm{g} / \mathrm{g})$ in triolein oil from semipermeable membrane devices (SPMDs) placed in storm drains, February 18/20 - March 13, 2003

\begin{tabular}{lccc}
\hline \multirow{2}{*}{ Site } & \multicolumn{3}{c}{ PCBs } \\
\cline { 2 - 4 } & $\begin{array}{c}\text { Aroclor- } \\
1248\end{array}$ & $\begin{array}{c}\text { Aroclor- } \\
1260\end{array}$ & Total \\
\hline KCP Storm drain sites & 31 & 8.2 & 38 \\
B lateral $^{\mathrm{a}}$ & 5.3 & & 5.3 \\
E lateral $^{\mathrm{a}}$ & 32 & & 32 \\
K lateral & 26 & & 26 \\
E 501/2 & 51 & & 51 \\
K 501/2 & 9.8 & 4.1 & 14 \\
N 501/2 & & & \\
& $<0.06$ & $<0.06$ & $<0.06$ \\
Trip blank & & & \\
\hline
\end{tabular}

${ }^{a}$ SPMDs damaged, $14-100 \mathrm{mg}$ of triolein recovered

${ }^{b}$ Deployed 2/20/2003, others on 2/18/2003 
Similar PCBs were also detected but at much lower concentrations in the SPMD placed at Outfall 001. This outfall serves as a high water overflow for the storm drain system that normally feeds Outfall 002, and thus occasionally receives water from the PCB-contaminated drain network. Since Outfall 001 would most likely only receive flow from the 002 drain system following periods of heavy rain and high flow, it is likely that substantial transport of particle-associated PCBs occurs via Outfall 001, which could deposit in the low gradient habitat of Boone Creek. No PCBs similar to Aroclor 1242 were detected in the SPMD exposed in Outfall 003 /004 (Table 6). Higher chlorinated PCBs similar to Aroclor 1260 were found in two SPMDs exposed in March 2003 (Table 7) within the outfall 002 storm drain system. No evidence of PCBs resembling Aroclor 1260 was found in the November sampling or at sites downstream from where it was found in March 2003. 



\section{DISCUSSION}

\section{Results in perspective}

PCBs are ubiquitous compounds in the aquatic environment, and the presence of low-level PCB concentrations in fish from urban streams like Indian Creek and the Blue River is not unexpected. In the US, PCBs were used in hundreds of commercial and industrial processes including electrical insulation, pigments for plastics, and plasticizers in paints. Over 1.5 billion pounds of PCBs were produced in the US prior to the ban on the manufacture and distribution of PCBs in the late 1970s. Once in the aquatic environment, PCBs are bioaccumulative and persistent compounds, and elevated levels in fish can be expected for many years. PCBs are second only to mercury in the number of lake acres (approximately 2 million) and river miles (approximately 120,000 ) in the US currently under a fish consumption advisory (EPA 2003). In EPA's National Fish Tissue Study (1999-2000) all 143 sites surveyed had detectable PCB levels in fish.

PCB concentrations in fish near the Kansas City Plant are at or below national norms for urban streams. Average PCB concentrations in fish were less than $0.1 \mu \mathrm{g} / \mathrm{g}$ at all sites monitored for this study, with the exception of channel catfish from BLK 27.0 and fish from Boone Creek (within the Kansas City Plant footprint) where mean concentrations were still less than $0.4 \mu \mathrm{g} / \mathrm{g}$. The maximum concentration in any individual fish collected for this study was $0.47 \mu \mathrm{g} / \mathrm{g}$. Of 362 sites sampled by EPA in their National Study of Chemical Residues in Fish (EPA 1992), the median concentration in fish tissue was $0.21 \mu \mathrm{g} / \mathrm{g}$ total PCBs, and $25 \%$ of the sites monitored exceeded 1 $\mu \mathrm{g} / \mathrm{g}$ in fish. The median concentration of total PCBs in whole fish collected from 100 urban streams over the 1992-2001 period by the USGS National Water Quality Assessment Program was $0.14 \mu \mathrm{g} / \mathrm{g}$ (USGS 2003). Fish from the most highly contaminated sites in the US, particularly large fatty fish like channel catfish, carp, and largemouth bass, often exceed $2 \mu \mathrm{g} / \mathrm{g}$ and can be as high as $50 \mathrm{ppm}$ (USGS 2003; EPA 1992).

Risks to people who eat fish is highly dependent on a number of factors, and many states have tailored advisories specific to the species of fish, fish size, type of consumer (e.g., children, pregnant women), and allowable total weight of fish eaten per month. Using standard risk assessment assumptions, EPA has established recommended consumption limits based on ranges of PCBs in fish tissue (EPA 1999). Based on EPA's reference dose (2 X $\left.10^{-5} \mathrm{mg} / \mathrm{kg}-\mathrm{d}\right)$ and cancer slope factor (2 per $\mathrm{mg} / \mathrm{kg}-\mathrm{d}$ ), some limits to eating fish would be recommended for almost all game fish in US lakes and rivers, since most of these fish species would be expected to contain greater than $0.0015 \mu \mathrm{g} / \mathrm{g}$ of PCBs. Using general EPA risk guidance, fish containing $0.05 \mu \mathrm{g} / \mathrm{g}$ PCBs (a level similar to Indian Creek fish averages) could be safely consumed at a rate of one 4-ounce meal per month (equivalent to 6 eight-ounce meals per year). Identification of specific risks associated with eating Indian Creek or Blue River fish is highly dependent on the assumptions used in the risk analysis.

There is considerable scientific and regulatory disagreement regarding the level of human health concern associated with PCB-contaminated fish, and states have dealt with the potential risks in very different ways. Some states have used EPA guidance as a basis for issuing detailed consumption limits for specific sites, even when PCB levels are very low. Other states have adopted statewide approaches that attempt to educate the public on overall ways to reduce risks (e.g., cutting off fatty tissue, grilling fish), and limit site-specific advisories to the most highly contaminated sites. In the case of Indian Creek and the Blue River, levels of PCBs in fish are such that the Missouri Department of Health does not designate a site-specific fish consumption advisory, but does provide general fish consumption guidance for state waters that could be useful to local anglers. The differences in opinion regarding perceived risks to the public are highlighted by the differences in the US regulatory agencies' PCB threshold limits in fish. Using the cancer health endpoint, EPA recommends no consumption of fish when PCB values in fish are $>0.1$; however, FDA sets the "no sale of commercial fish across state lines" threshold at $\geq 2 \mu \mathrm{g} / \mathrm{g}$ (20 times higher). Both regulatory 
agencies point out that that there are considerable health benefits from eating fish that are not considered in conventional risk analyses.

The levels of chlordane in fish reported for this study are very low, with average concentrations less than or equal to $0.02 \mu \mathrm{g} / \mathrm{g}$ for the sum of analyzed isomers. Such low levels are consistent with observed decreases in chlordane concentration in fish analyzed by state of Missouri regulatory agencies over the last decade. The Missouri Department of Health (MDH) issued a fish consumption advisory (one meal per week) for the Blue River in 1985 due to chlordane contamination. In the 2001 state fish advisory, MDH removed its advisory against consuming catfish, carp, buffalo, drum, suckers, and paddlefish due to the reduction of chlordane contamination in Blue River fish. Chlordane concentrations in carp in the Blue River declined by more than $90 \%$ between 1985 and 2000 (Missouri Dept. of Conservation 2001). A similar decrease was noted in channel catfish, which averaged $0.08 \mathrm{mg} / \mathrm{kg}$ in 1998. Such decreases in chlordane in the Blue River are consistent with national trends, and reflect the discontinuation of this chemical as a commercial pesticide.

\section{Spatial patterns of contamination in stream biota}

Biological sampling sites were chosen to bracket the major discharges from KCP to Indian Creek and the Blue River. Aroclor 1242 was detected in green sunfish at low concentrations $(<0.1$ $\mathrm{ug} / \mathrm{g}$ ) at the two most downstream sites on Indian Creek (ICK 1.0 and ICK 0.2) and at the most downstream site on the Blue River (BLK 25.0) (Fig. 4). The highest concentrations of Aroclor 1242 were found in green sunfish from Boone Creek. No lower-chlorinated PCBs were found in fish at BLK 27.0 (downstream of the confluence with Indian Creek) or at the two sites upstream of KCP discharges (ICK 3.0 and BLK 31.0). Taken together with the Aroclor 1242 data in SPMDs placed at $\mathrm{KCP}$ outfalls, the spatial pattern of contamination suggests that the KCP is the likely source of the lower chlorinated PCBs in Indian Creek and Blue River fish (Fig. 4).

A similar spatial pattern of PCB bioaccumulation was evident for the higher chlorinated PCBs (Aroclor 1254 and 1260), but there was evidence of higher chlorinated PCBs in fish upstream of KCP discharges (Figs. 5). PCBs were detected in green sunfish at ICK 3.0 (upstream of the Holmes Road dam) and in channel catfish and Asiatic clams at BLK 31.0 (Fig. 6).

Sampling three species provided information on PCB exposure as well as species differences in PCB uptake (Fig. 6). In general, PCBs in fish were slightly higher in Indian Creek downstream of the KCP discharges, but there was some evidence of PCB inputs upstream of the KPC as well. Somewhat surprisingly, channel catfish in lower Indian Creek had PCB concentrations that were similar to those found in green sunfish. PCBs were not detected in clams in Indian Creek. Clams closing their shells as a result of poor water quality in this section could explain the absence of PCBs in clams from ICK 0.2. Peterson et al. 1994 found that clams substantially underestimated PCB exposure when exposed to chlorine levels that reduced filtering time.

Concentrations of PCBs were generally higher in fish from the Blue River than in those from Indian Creek. PCB concentrations in fish the two lower sites in the Blue River exceeded those in fish from the upstream Blue River site (upstream of the Indian Creek mouth). Not unexpectedly, channel catfish, which are larger, older, and contain greater intramuscular lipids than green sunfish, had higher concentrations of total PCBs than green sunfish from the same site.

Fish with the highest mean PCB concentration were those collected in Boone Creek (0.39 ug/g; Fig. 6). This finding may be related to the limited habitat in Boone Creek and the fish's proximity to the discharge. The fish collected in Boone Creek were concentrated within a few pools immediately below the 001 discharge.

Chlordane concentrations in channel catfish were low at all sites. Although concentrations were slightly higher at ICK 0.2 and BLK 27.0 than at BLK 31.0 (Table 4), the ability to make spatial comparisons with these data is limited by the presence of near-detection limit values along with the small difference between sites. 


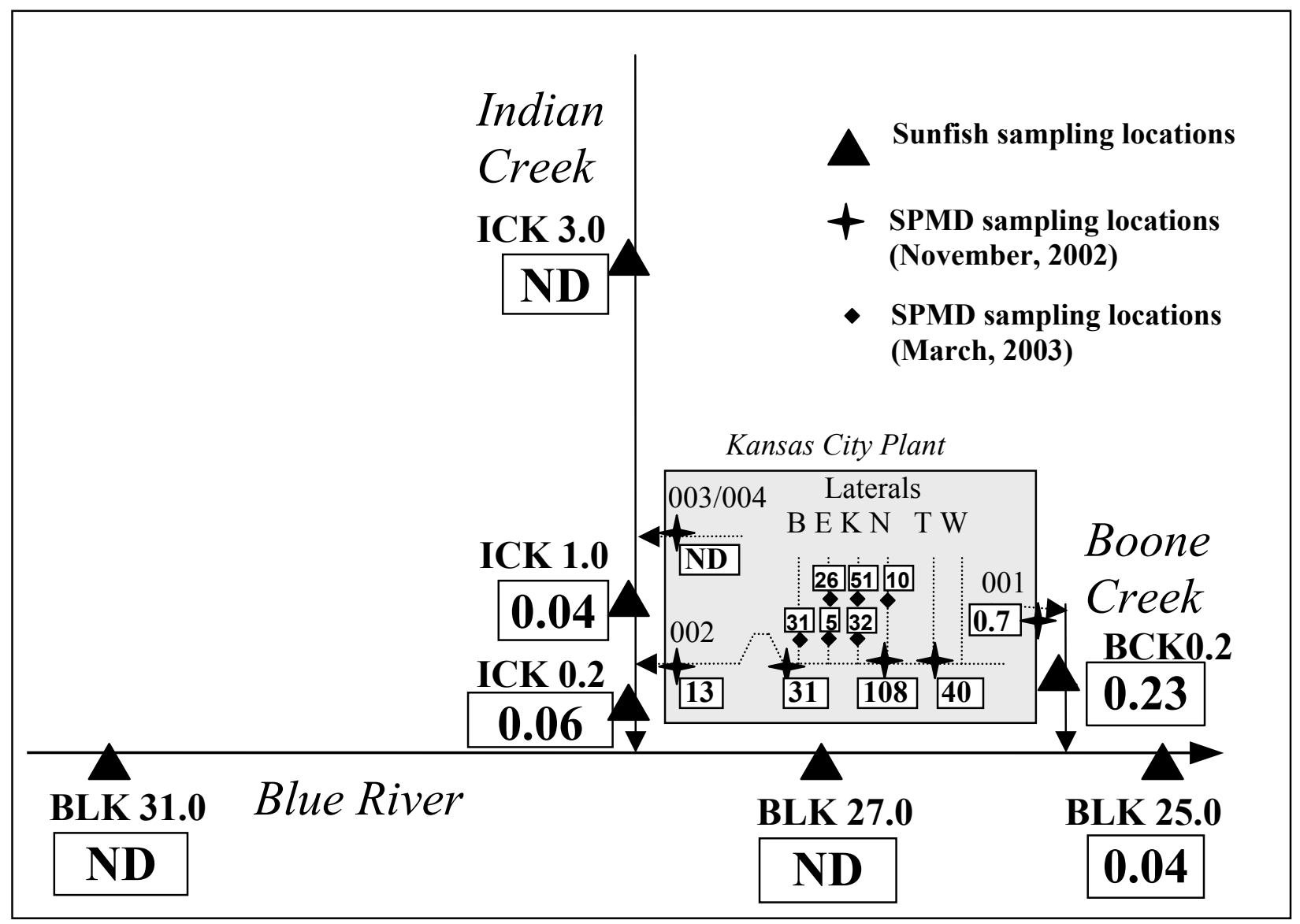

Fig 4. Schematic showing spatial pattern of Arochlor-1242 in sunfish and SPMDs near and within the Kansas City Plant as a result of the present study. SPMD results from March 2003 were identified as PCB 1248. 


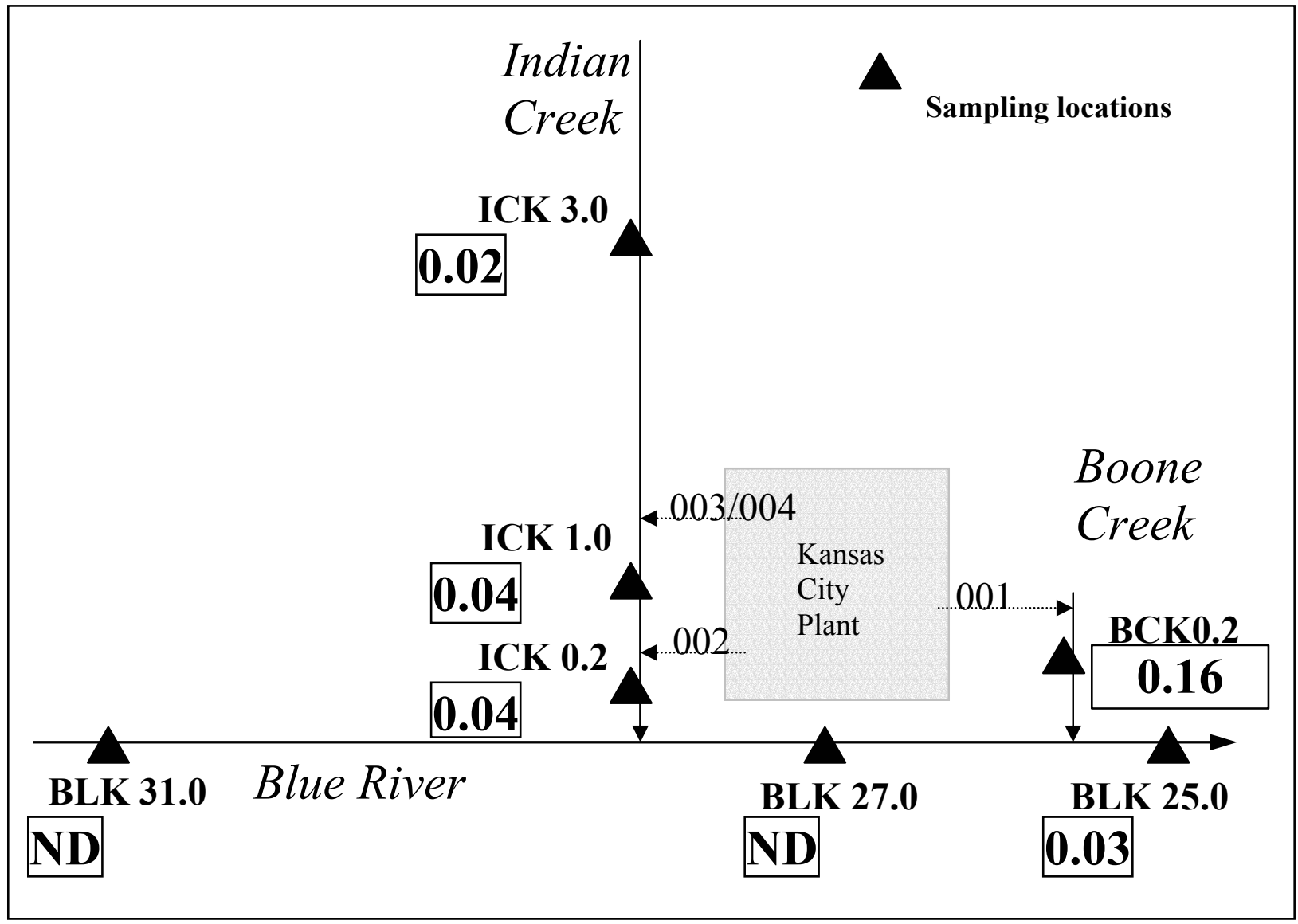

Fig. 5. Schematic showing spatial pattern of higher chlorinated Arochlors (Arochlor $1254+$ 1260) in sunfish collected near the Kansas City Plant, November 2002. 


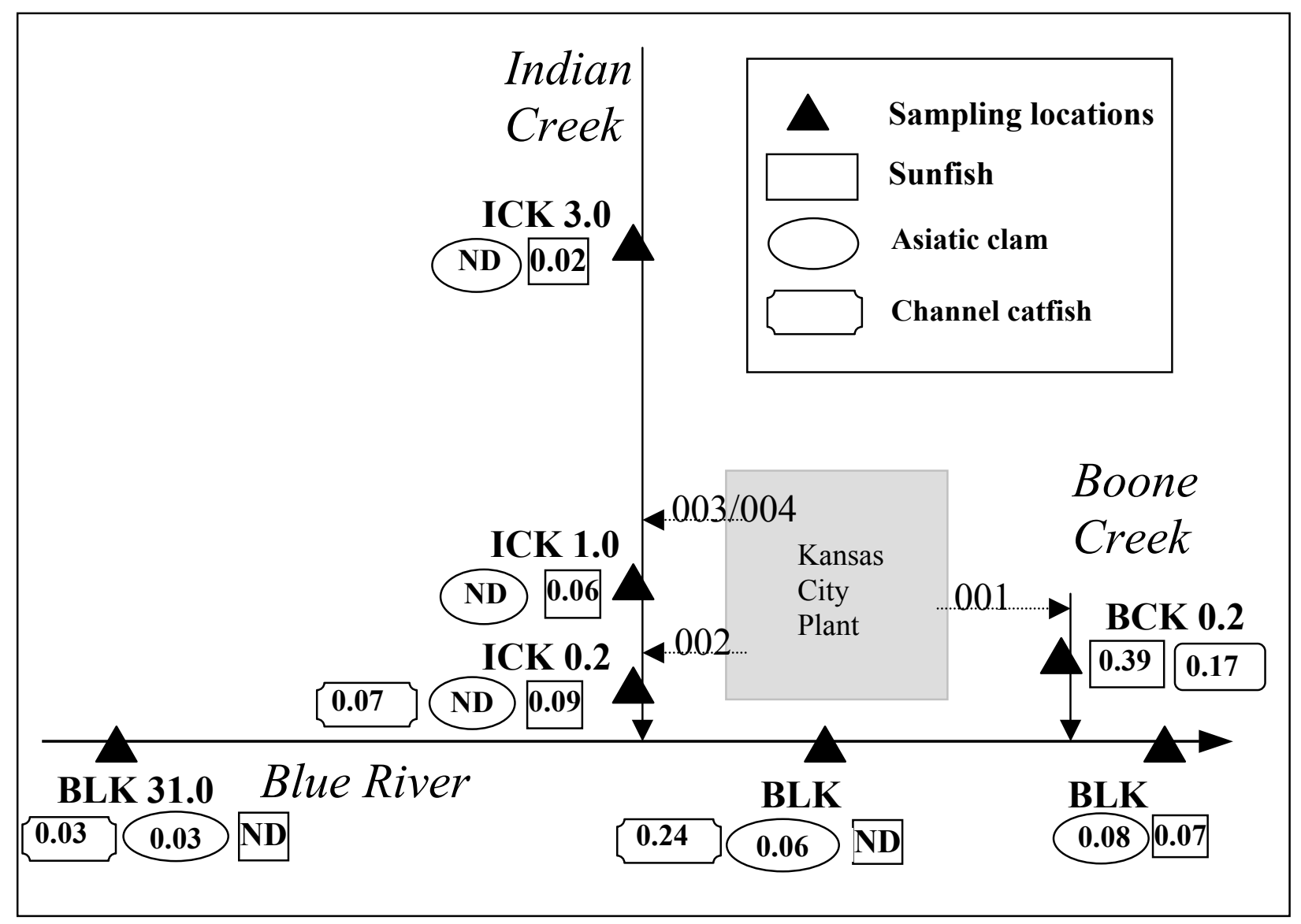

Fig. 6. Schematic showing spatial distribution of mean total PCB concentrations in three species collected near KCP in November, 2002: green sunfish, Asiatic clams, and channel catfish. 


\section{PCB source investigation using SPMDs}

The deployment of SPMDs in the storm drain network can be used to evaluate the relative importance of PCB inputs from the KCP to receiving streams. In the November 2002 deployment, the highest concentration $(108 \mu \mathrm{g} / \mathrm{g})$ was at the junction of Lateral $\mathrm{N}$ and the trunk line leading to the outfall (Fig. 4). The March 2003 deployment tested different locations, and found the highest PCB concentration $(51 \mu \mathrm{g} / \mathrm{g})$ in the upper reach of Lateral $\mathrm{K}$.

PCB values in SPMDs are semi-quantitative measurements, and the numerical values should not be used as precise indicators of PCB concentrations in the overlying water. Even if they were precise measures, the comparison of data from November 2002 and March 2003 would not be indicative of relative source strength, since different flow regimes between the two periods would certainly influence mean aqueous PCB concentrations. Overall, however, the data portray a fairly ubiquitous presence of PCBs resembling Aroclor 1242 in virtually the entire storm drain system above, and including, Outfall 002 (Laterals T and W were not sampled). PCB concentrations found in KCP discharge 002 could explain the Aroclor 1242 levels found in fish in Indian Creek and the Blue River downstream from that discharge.

The difference in Aroclor identification between fall (Aroclor 1242) and spring deployments (Aroclor 1248) is not surprising. PCB mixtures extracted from environmental samples seldom identically match the commercial mixtures with which they are compared and quantified, because various environmental transport mechanisms act separately on each component (congener) present in the original PCB mixture. Both of these Aroclors are in the low-chlorinated range of PCBs. The differential water solubility, volatility, and susceptibility to microbial degradation of these congers act to change their proportions in environmental media. A degree of subjectivity is therefore introduced when the analyst must classify an environmental PCB extract according to which commercial PCB mixture (Aroclor) it most closely resembles. Most environmental weathering processes act to remove the less chlorinated components of the original PCB mixture, thus giving it the appearance of a more highly chlorinated mixture. For that reason, it would not be surprising to find environmental extracts of PCBs, which were originally Aroclor 1242, classified as Aroclor 1248. Identification of a PCB extract as Aroclor 1248 does not obviate the likelihood that its source was originally Aroclor 1242. High flows that occurred during the February/March exposure may have depleted SPMDs of some of the more water-soluble (and typically less chlorinated) congeners, making the final extract look more like Aroclor 1248.

\section{Temporal trends}

Evaluating contaminant trends in fish over time is a useful way to gauge the effectiveness of remediation efforts. However, care should be taken to not over interpret small changes in PCB levels. Although there was a significant effort to be consistent in the sites, species, and methodologies used over time, PCB data presented here does include a mix of analytical methods, as well as small differences in the number and size of fish collected. Sampling surveys also represent snapshots in time. PCB concentrations in fish from small streams exhibit substantial short-term changes, often increasing or decreasing more than $50 \%$ between semiannual sampling periods (Southworth et al 1997). Lower chlorinated PCB mixtures, such as Aroclor 1242, would be expected to be more readily eliminated by fish, and thus turn over faster than mixtures such Aroclor 1260. Thus, a single high or low flow period may represent unusual conditions that may change PCB levels in fish over month long time scales. Trending over multiple years, such as was done here for at the KCP, should be viewed as providing a general indication of overall trends.

PCB concentrations in green sunfish in 2002 were near the lowest reported, and have decreased substantially since relatively high levels were reported in the early 1990s. This trend was most dramatic in Indian Creek, where all sites, including the site above the KCP discharges, showed decreasing total PCB values since 1993. The spatial pattern in Indian Creek in 2002 is consistent 
with the pattern observed in all previous years; the highest PCB concentrations in fish are at ICK 0.2 and levels decrease with distance upstream (Fig. 7).

PCB concentrations in sunfish from the Blue River have also decreased since the early 1990s, although the pattern is less clear (Fig. 8). PCBs in fish from the Blue River have been low but frequently detectable at the site above the confluence with Indian Creek. The highest concentrations of PCBs in sunfish occurred in the 1993 study, and the concentrations observed in the 2002 study are a small fraction of those relatively high levels.

Mean PCB concentrations in fish collected from Boone Creek in 2002 are the highest reported to date, but are very similar to those observed in 1993 (Fig. 9). Changes in PCB concentrations in fish from Boone Creek are likely to be influenced by year-to-year differences in species (occasionally bluegill were collected in previous years), fish size, and the collection's proximity to the discharge. PCB concentrations in Boone Creek fish may be a result of Outfall 001 inputs, historical instream sediment contamination, or inputs from a landfill adjacent to the north bank of the creek immediately below Outfall 001 . The 87th and Prospect Landfill Site was operated by Kansas City, Missouri, from 1958-1971 (Betzen 1995). After it was used for the disposal of a variety of municipal, sanitary, and industrial wastes, it was closed and capped with a 3-foot clay cover. Although this clay cap was designed to promote runoff from precipitation and limit the infiltration of water, the potential for infiltration is increased by the static head of the water that ponds within the Boone Creek storm water retention basin that is located behind the levee and over the closed landfill. An increase in infiltration could mobilize contaminants present within the landfill, and the likely route of groundwater movement would be toward Boone Creek to the south. Indeed, low concentrations of metals and organics were detected during EPA testing of seeps along the southwest boundary of the landfill (Betzen 1995).

Mean PCB concentrations in channel catfish exhibit trends similar to those observed in green sunfish (Fig. 10). The highest PCB concentrations were found in catfish collected in 1991 and 1992, and much lower levels were observed in the present study. In the previous studies, high PCB concentrations were found in catfish from the upstream Blue River reference site (BLK 31), but concentrations observed in 2002 were substantially lower. Such differences could be due to decreases in upstream exposure, or to differences in the distribution patterns of catfish (i.e. fish in the present study move less and are more localized in less contaminated water/sediment upstream).

Like PCBs, chlordane concentrations in channel catfish have also decreased since the 1990s (Fig. 11). This reduction in chlordane levels in fish is similar to the slow decrease in concentration levels observed statewide, a trend that has been attributed to the removal of chlordane from the market by EPA in 1988 (Carlson 2002). 


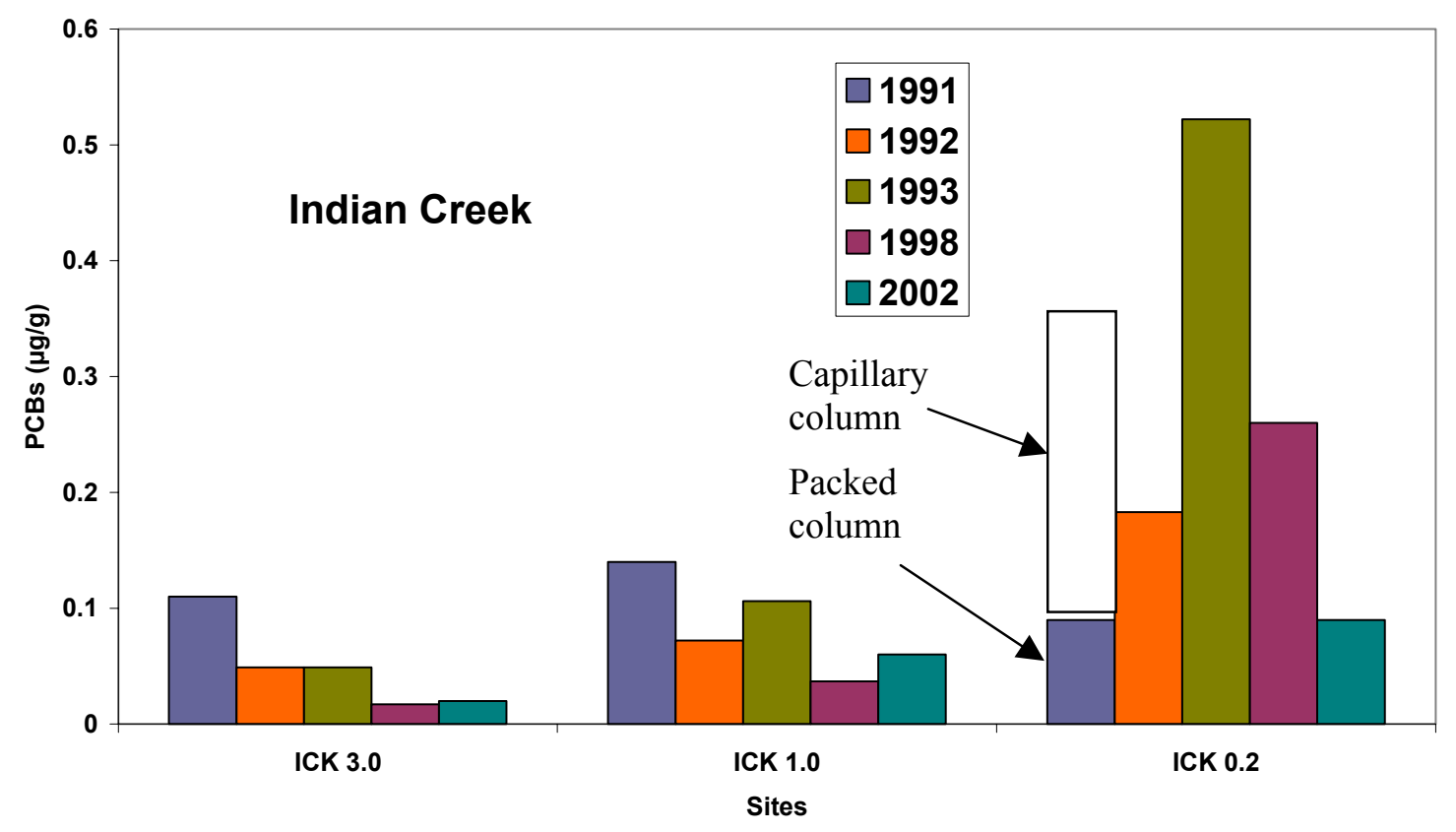

Fig. 7. Mean PCB concentrations in Indian Creek green sunfish in 2002 relative to mean values found in previous sampling years.

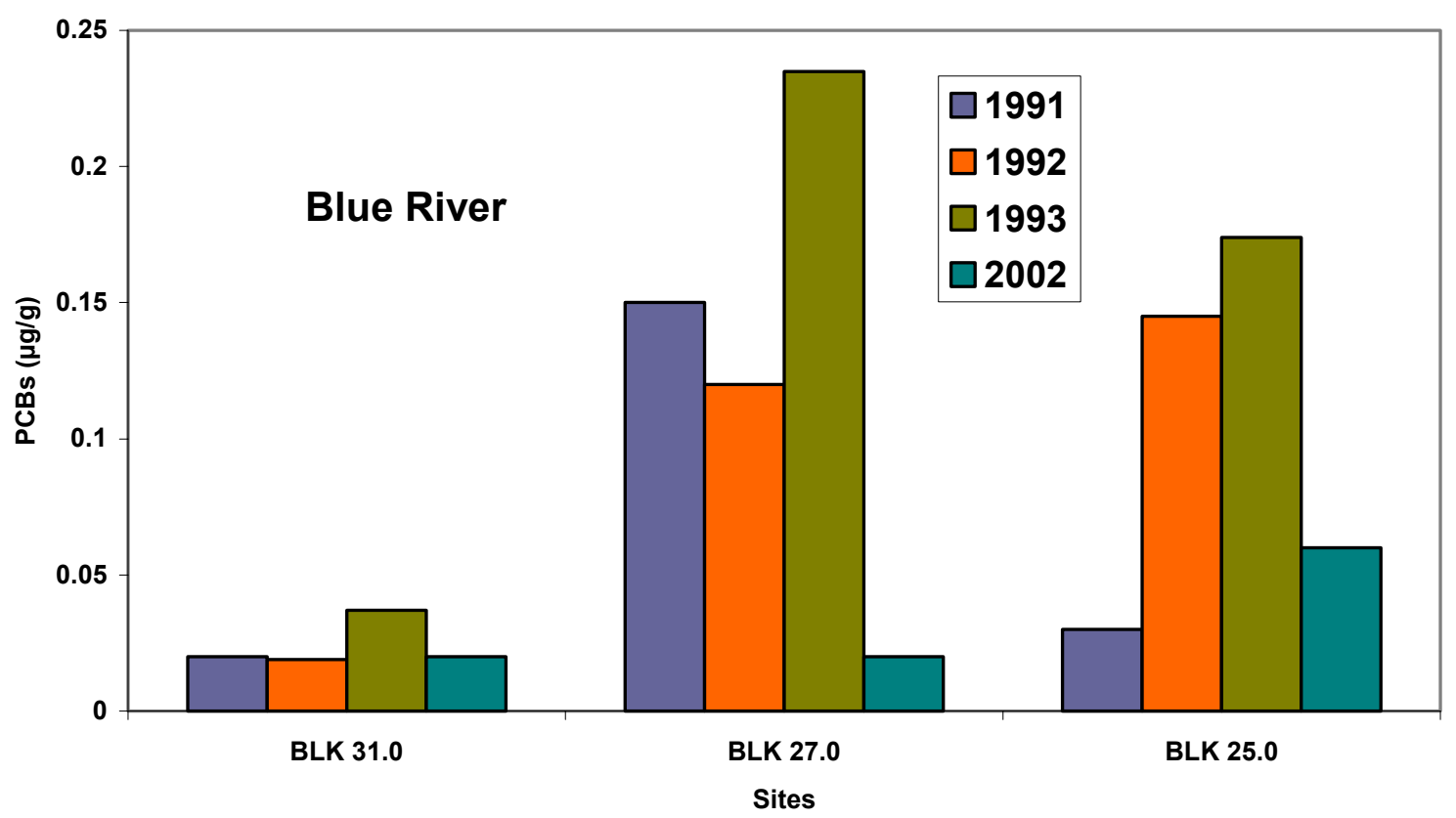

Fig. 8. Mean PCB concentrations in Blue River green sunfish in 2002 relative to mean values found in previous sampling years. 


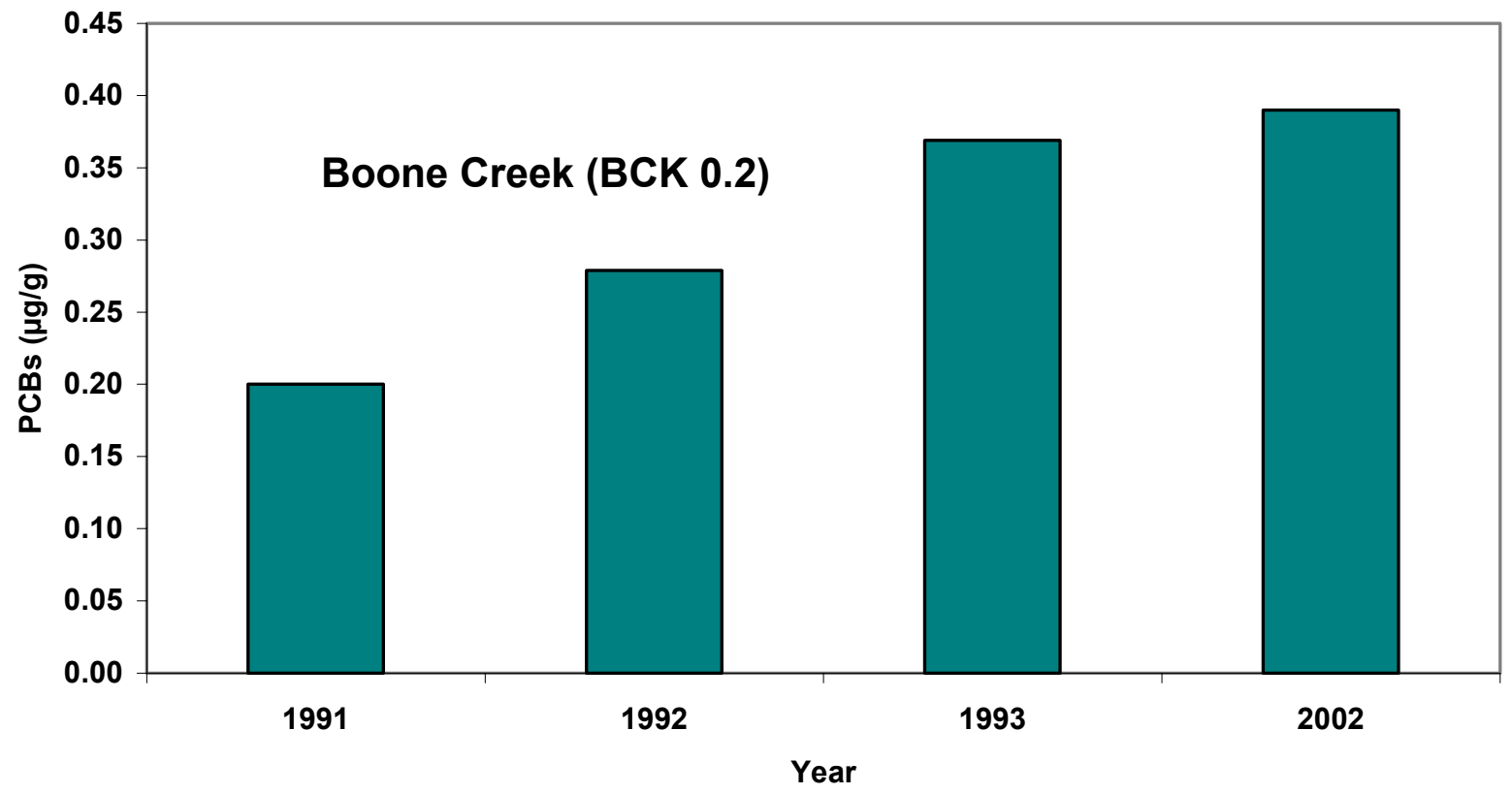

Fig. 9. Mean PCB concentrations in Boone Creek green sunfish in 2002 relative to mean values found in previous sampling years.

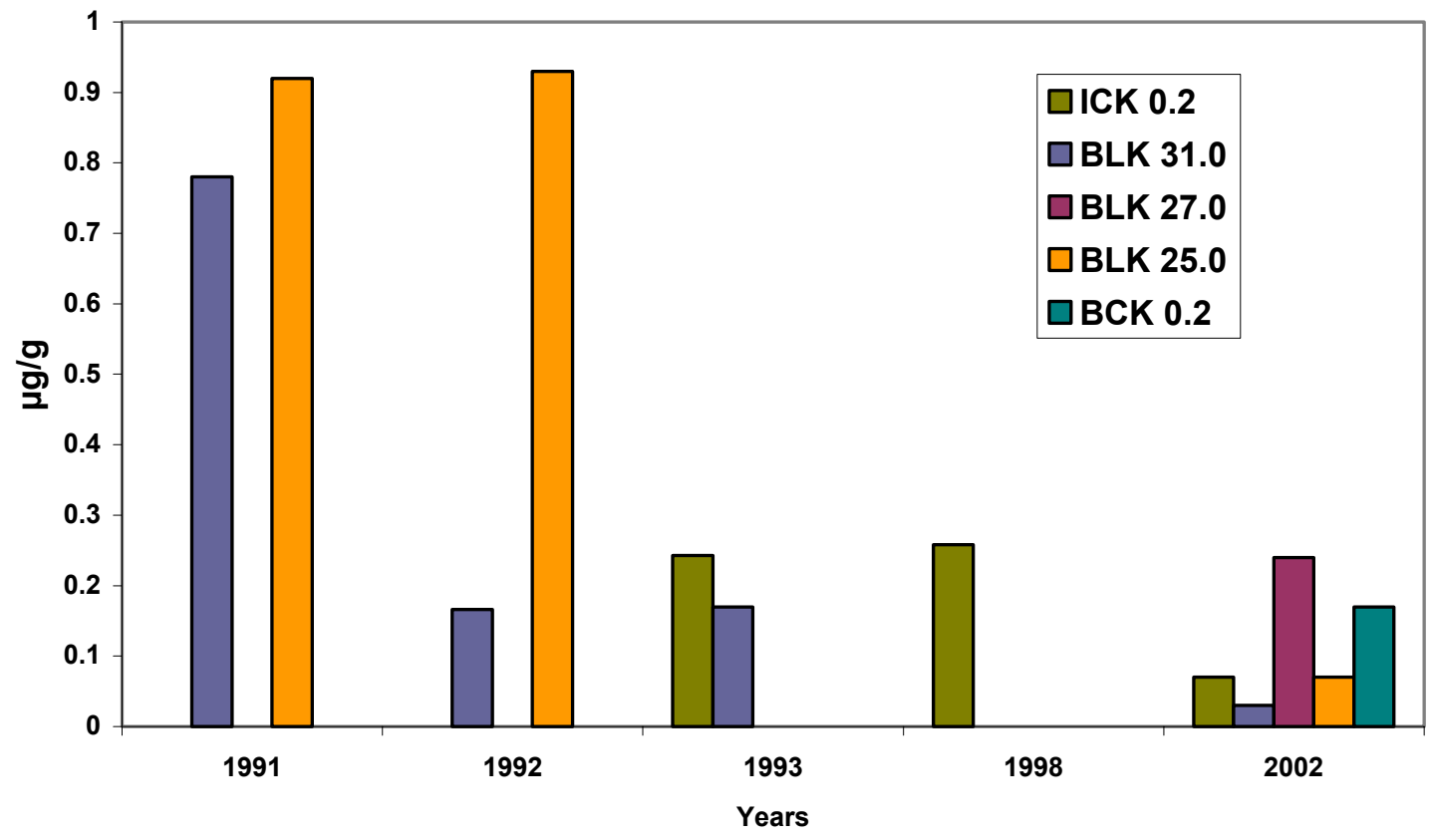

Fig. 10. Mean PCB concentrations in channel catfish over time. 


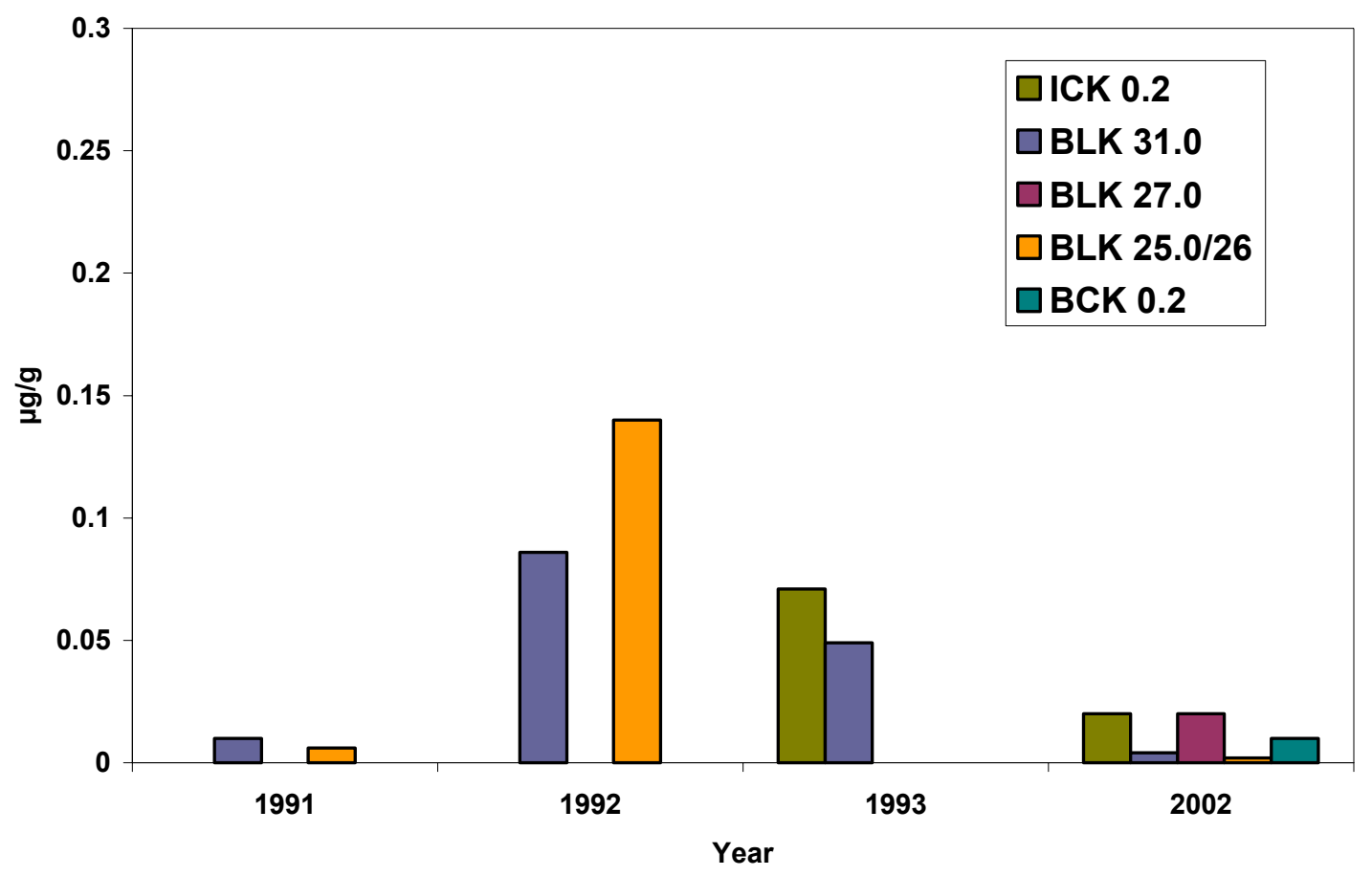

Fig. 11. Mean Chlordane concentrations in channel catfish over time. 


\section{CONCLUSIONS}

The concurrent monitoring of a variety of biotic and abiotic media for the present study, across a number of sites upstream and downstream of KCP discharges, provides a valuable picture of PCB exposure and bioaccumulation in Indian Creek and the Blue River. Similar patterns of contamination, both spatially and temporally, were observed across species and media, providing additional confidence in the observed values. Monitoring of storm drains within the KCP plant was also useful in evaluating the relative role of $\mathrm{KCP}$ on bioaccumulation in surrounding waters.

Following are some key conclusions that can be drawn from this study:

- $\quad$ PCB and chlordane concentrations in Indian Creek and Blue River fish are relatively low, and similar to many national urban sites. Potential risks to humans who eat fish from Indian Creek or the Blue River is highly dependent on assumptions used in the risk analysis.

- Very low PCB concentrations were observed in Asiatic clams at the Blue River sites; no PCBs were detected in clams from Indian Creek.

- Results of SPMD sampling during two separate four-week periods indicate ubiquitous, low-level contamination of the storm drain network leading to outfall 002 with PCBs similar to Aroclor 1242 .

- The spatial pattern of Aroclor 1242 contamination in fish, in concert with Aroclor 1242 results in storm drain SPMDs, suggests that the KCP has contributed to the PCB body burdens of fish in the receiving streams.

- The presence of PCBs in fish near the KCP is at least partially due to other sources of PCBs to the watershed, as evidenced by detectable levels of the higher chlorinated PCBs in biota upstream of the plant.

- The levels of PCBs and chlordane in fish in 2002 are substantially lower than the levels observed in the early 1990s. 



\section{REFERENCES}

Ashwood, T.L., and M.J. Peterson. 1994. Polychlorinated Biphenyls and Pesticides in Fish from Streams near the U.S. Department of Energy's Kansas City Plant: 1993 Report. Draft ORNL/TM12892. Oak Ridge, Tennessee.

Ashwood, T.L., G.R. Southworth, and M.J. Peterson. 1993. Polychlorinated Biphenyls and Pesticides in Fish from Streams near the U.S. Department of Energy's Kansas City Plant. ORNL/TM-12298. Oak Ridge National Laboratory, Oak Ridge, Tennessee.

Ashwood, T.L., and M. J. Peterson. 1994. Polychlorinated Biphenyls and Pesticides in Fish from Streams near the U.S. Department of Energy's Kansas City Plant: 1993 Report. ORNL/TM-12892. Oak Ridge National Laboratory, Oak Ridge, Tennessee.

Ashwood, T.L. 1998. Polychlorinated Biphenyl Concentrations in Fish from Indian Creek. Letter Report from T.L. Ashwood, Oak Ridge National Laboratory, to A.D. Laase, DOE Kansas City Plant, September 14, 1998.

Betzen, G.A. 1995. Review of General Investigation of Flood Damage Reduction for Blue River at Dodson Industrial District, Draft Feasibility report and Environmental Assessment, October 1995. Letter from G.A. Betzen, DOE Kansas City Plant, to J. Lilley, U.S. Army Corps of Engineers-Kansas City, December 19, 1995.

Carlson, G. 2002. Health Department Adviser Missourians on Fish Safety. News Release, July 25, 2002. Missouri Department of Health, Jefferson City Missouri.

EPA (U.S. Environmental Protection Agency).1986. Test Methods for Evaluating Solid Waste. SW846, Third Edition. Office of Solid Waste and Emergency Response, U.S. Environmental Protection Agency, Washington, D.C.

EPA (U.S. Environmental Protection Agency). 1995. Guidance for Assessing Chemical Contaminant Data for Use in Fish Advisories. Volume 1, Fish Sampling and Analysis, Second Edition. EPA 823R-95-007. Office of Water, U.S. Environmental Protection Agency, Washington D.C.

EPA (U.S. Environmental Protection Agency). 2003. EPA Fact Sheet. Polychlorinated Biphenyls (PCBs) Update: Impact on Fish Advisories. EPA 823-F-99-019. Office of Water, U.S.

Environmental Protection Agency, Washington D.C.

EPA (U.S. Environmental Protection Agency). 2003. EPA Fact Sheet. EPA Update: National listing of Fish and Wildlife advisories. EPA 823-F-03-003. Office of Water, U.S. Environmental Protection Agency, Washington D.C.

Huckins, J.N., M.U. Tubergen, and G.K. Manuweera. 1990. Semipermeable Membrane Devices containing a model lipid: a new approach to monitoring the bioavailability of lipophilic contaminants and estimating their bioconcentration potential. Chemosphere 20(5), 533-552.

McCarthy, J. F., G.R. Southworth, K.D.Ham, and J.A. Palmer. 2000. Time Integrated, Flux-based Monitoring Using Semipermeable Membrane Devices to Estimate the Contribution of Industrial Facilities to Regional Polychlorinated Biphenyl Budgets. Envtl. Toxicol. Chem. 19:352 - 359. 
Missouri Dept. of Conservation. 2001. Four Phased Total Maximum Daily Loads (TMDLs) for the Blue River, Pollutant: Chlordane. http:/www.epa.gov/region7/water/pdf/BlueRiverFinalTMDL.pdf

Peterson, M. J., G. R. Southworth, and K. D. Ham. 1994. Effect of sublethal chlorinated discharges on PCB accumulation in transplanted Asiatic clams (Corbicula fluminea). Water, Air, and Soil Pollution 73:169-178.

Pitchford, G.D., R.D. Pulliam, K.P. Sullivan and P.J. Jeffries. 1999. Blue River Watershed Inventory and Assessment. Kansas City Regional Fisheries Office, Missouri Department of Conservation, Blue Springs, Missouri.

Southworth, G.R., G.F. Cada, L.A. Kszos, M.J. Peterson, E.M. Schilling, J.G. Smith, A.J. Stewart, and R. L. Hinzman. 1997. Monitoring ecological recovery in a stream impacted by contaminated groundwater. Proceedings, 70th Annual Conference of Water Environment Federation.

Southworth, G.R., A.J. Stewart, M.J. Peterson, and T.L. Ashwood. 1992. Bioaccumulation Monitoring and Toxicity Testing in Streams and Groundwater Wells at the U.S. Department of Energy Kansas City Plant. ORNL/TM-11932. Oak Ridge National laboratory, Oak Ridge, Tennessee.

USGS (United States Geological Survey). 2003. Organochlorine Pesticides and PCBs in Bed Sediment and Whole Fish from United States Rivers and Streams: Summary Statistics; Preliminary Results from Cycle I of the National Water Quality Assessment Program (NAWQA), 1992-2001. http://ca.water.usgs.gov/pnsp/oc_doc.html. 
APPENDIX A

SAMPLE DATA 
Table A-1. Field and laboratory data for individual green sunfish (GRSUNF) and channel catfish (CHNCAT) collected from sites on Indian Creek (ICK), Blue River (BLK), and Boone Creek (BCK) near the Kansas City Plant, October-November 2002. (N/A = not analyzed)

\begin{tabular}{|c|c|c|c|c|c|c|c|c|c|c|c|c|c|}
\hline Site & $\begin{array}{c}\text { Collection } \\
\text { Date }\end{array}$ & Species & Sex & $\begin{array}{l}\text { Tag } \\
\text { No. }\end{array}$ & $\begin{array}{c}\text { Length } \\
(\mathrm{cm})\end{array}$ & $\begin{array}{c}\text { Weight } \\
\text { (g) }\end{array}$ & $\begin{array}{l}\text { PCB } \\
1242^{\mathrm{a}} \\
\end{array}$ & $\begin{array}{l}\text { PCB } \\
1248 \\
\end{array}$ & $\begin{array}{l}\text { PCB } \\
1254 \\
\end{array}$ & $\begin{array}{l}\text { PCB } \\
1260^{a} \\
\end{array}$ & $\begin{array}{c}\text { Total } \\
\text { PCBs }^{\mathbf{a}, \mathrm{b}}\end{array}$ & $\begin{array}{c}\text { Alpha } \\
\text { Chlordane }^{c}\end{array}$ & $\begin{array}{c}\text { Gamma } \\
\text { Chlordane } \\
\end{array}$ \\
\hline ICK 0.2 & $11 / 12 / 2002$ & GRSUNF & M & 11480 & 15.0 & 65.2 & $<0.012$ & $<0.01$ & $<0.013$ & $<0.0045$ & $0.05 \mathrm{U}$ & $\mathrm{N} / \mathrm{A}$ & N/A \\
\hline ICK 0.2 & $11 / 12 / 2002$ & GRSUNF & M & 11481 & 11.7 & 30.4 & $<0.025$ & $<0.022$ & $<0.028$ & $<0.0096$ & $0.10 \mathrm{U}$ & N/A & N/A \\
\hline ICK 0.2 & $11 / 12 / 2002$ & GRSUNF & M & 11485 & 15.9 & 72.4 & $<0.015$ & $<0.013$ & $<0.017$ & $<0.0058$ & $0.06 \mathrm{U}$ & N/A & N/A \\
\hline ICK 0.2 & $11 / 12 / 2002$ & GRSUNF & M & 11486 & 11.8 & 28.8 & 0.26 & $<0.016$ & $<0.02$ & 0.12 & 0.38 & N/A & N/A \\
\hline ICK 0.2 & $11 / 12 / 2002$ & GRSUNF & M & 11520 & 11.7 & 30.8 & 0.061 & $<0.011$ & $<0.014$ & 0.052 & 0.11 & N/A & N/A \\
\hline ICK 0.2 & $11 / 12 / 2002$ & GRSUNF & M & 11521 & 13.6 & 54.2 & $<0.027$ & $<0.024$ & $<0.03$ & $<0.01$ & $0.11 \mathrm{U}$ & N/A & N/A \\
\hline ICK 0.2 & $11 / 12 / 2002$ & GRSUNF & M & 11522 & 13.0 & 43.2 & $<0.026$ & $<0.023$ & $<0.029$ & $<0.01$ & $0.10 \mathrm{U}$ & N/A & N/A \\
\hline ICK 0.2 & $11 / 12 / 2002$ & GRSUNF & $\mathrm{M}$ & 11523 & 12.1 & 33.5 & $0.067 \mathrm{~J}$ & $<0.022$ & $<0.028$ & $0.07 \mathrm{~J}$ & 0.14 & N/A & N/A \\
\hline ICK 1.0 & $11 / 13 / 2002$ & GRSUNF & $\mathrm{M}$ & 11450 & 16.5 & 100.4 & $<0.015$ & $<0.013$ & $<0.016$ & $0.036 \mathrm{~J}$ & $0.04 \mathrm{~J}$ & N/A & N/A \\
\hline ICK 1.0 & $11 / 13 / 2002$ & GRSUNF & $\mathrm{F}$ & 11451 & 15.1 & 54.9 & $<0.016$ & $<0.014$ & $<0.018$ & $<0.0061$ & $0.06 \mathrm{U}$ & N/A & N/A \\
\hline ICK 1.0 & $11 / 13 / 2002$ & GRSUNF & $\mathrm{F}$ & 11452 & 12.9 & 35.0 & $<0.025$ & $<0.022$ & $<0.028$ & $0.041 \mathrm{~J}$ & $0.04 \mathrm{~J}$ & N/A & N/A \\
\hline ICK 1.0 & $11 / 13 / 2002$ & GRSUNF & M & 11453 & 12.5 & 35.6 & 0.13 & $<0.019$ & $<0.024$ & $0.07 \mathrm{~J}$ & 0.20 & N/A & N/A \\
\hline ICK 1.0 & $11 / 13 / 2002$ & GRSUNF & M & 11454 & 13.1 & 41.9 & $<0.021$ & $<0.018$ & $<0.023$ & $0.055 \mathrm{~J}$ & $0.06 \mathrm{~J}$ & N/A & N/A \\
\hline ICK 1.0 & $11 / 13 / 2002$ & GRSUNF & $\mathrm{M}$ & 11455 & 12.6 & 34.5 & $<0.023$ & $<0.02$ & $<0.025$ & $<0.0086$ & $0.09 \mathrm{U}$ & N/A & N/A \\
\hline ICK1.0 & $11 / 13 / 2002$ & GRSUNF & $\mathrm{F}$ & 11456 & 11.7 & 28.4 & $<0.028$ & $<0.025$ & $<0.031$ & $0.076 \mathrm{~J}$ & $0.08 \mathrm{~J}$ & N/A & N/A \\
\hline ICK 1.0 & $11 / 13 / 2002$ & GRSUNF & $\mathrm{F}$ & 11457 & 12.0 & 28.0 & $<0.025$ & $<0.022$ & $<0.028$ & $0.039 \mathrm{~J}$ & $0.04 \mathrm{~J}$ & $\mathrm{~N} / \mathrm{A}$ & N/A \\
\hline ICK3.0 & $11 / 13 / 2002$ & GRSUNF & $\mathrm{F}$ & 11500 & 14.9 & 57.4 & $<0.013$ & $<0.012$ & $<0.015$ & $<0.0051$ & $0.05 \mathrm{U}$ & N/A & N/A \\
\hline ICK 3.0 & $11 / 13 / 2002$ & GRSUNF & $\mathrm{I}^{\mathrm{d}}$ & 11501 & 14.0 & 50.2 & $<0.016$ & $<0.014$ & $<0.018$ & $0.037 \mathrm{~J}$ & $0.04 \mathrm{~J}$ & N/A & N/A \\
\hline ICK 3.0 & $11 / 13 / 2002$ & GRSUNF & M & 11502 & 13.0 & 41.9 & $<0.018$ & $<0.015$ & $<0.02$ & $0.031 \mathrm{~J}$ & $0.03 \mathrm{~J}$ & N/A & N/A \\
\hline ICK 3.0 & $11 / 13 / 2002$ & GRSUNF & $\mathrm{F}$ & 11503 & 13.1 & 38.6 & $<0.02$ & $<0.018$ & $<0.022$ & $<0.0077$ & $0.08 \mathrm{U}$ & N/A & N/A \\
\hline ICK 3.0 & $11 / 13 / 2002$ & GRSUNF & $\mathrm{F}$ & 11504 & 12.5 & 34.1 & $<0.023$ & $<0.02$ & $<0.026$ & $<0.0089$ & $0.09 \mathrm{U}$ & N/A & N/A \\
\hline ICK 3.0 & $11 / 13 / 2002$ & GRSUNF & M & 11505 & 12.7 & 38.8 & $<0.021$ & $<0.016$ & $<0.019$ & $<0.021$ & $0.07 \mathrm{U}$ & N/A & N/A \\
\hline ICK3.0 & $11 / 13 / 2002$ & GRSUNF & $\mathrm{F}$ & 11506 & 12.3 & 31.7 & $<0.016$ & $<0.012$ & $<0.014$ & $<0.016$ & $0.05 \mathrm{U}$ & N/A & N/A \\
\hline ICK 3.0 & $11 / 13 / 2002$ & GRSUNF & $\mathrm{M}$ & 11507 & 11.7 & 30.4 & $<0.03$ & $<0.024$ & $<0.028$ & $<0.031$ & $0.11 \mathrm{U}$ & N/A & N/A \\
\hline BLK25.0 & $11 / 12 / 2002$ & GRSUNF & $\mathrm{F}$ & 11390 & 13.4 & 51.3 & $0.061 \mathrm{~J}$ & $<0.015$ & $<0.019$ & $0.038 \mathrm{~J}$ & 0.10 & N/A & N/A \\
\hline BLK25.0 & $11 / 12 / 2002$ & GRSUNF & $\mathrm{M}$ & 11391 & 14.5 & 65.4 & $0.033 \mathrm{~J}$ & $<0.012$ & $<0.015$ & 0.062 & 0.10 & N/A & N/A \\
\hline BLK25.0 & $11 / 12 / 2002$ & GRSUNF & M & 11392 & 15.8 & 80.9 & 0.064 & $<0.0095$ & $<0.012$ & $0.026 \mathrm{~J}$ & 0.09 & N/A & N/A \\
\hline BLK25.0 & $11 / 12 / 2002$ & GRSUNF & M & 11393 & 11.1 & 29.4 & $0.05 \mathrm{~J}$ & $<0.025$ & $<0.031$ & $0.082 \mathrm{~J}$ & 0.13 & N/A & N/A \\
\hline BLK25.0 & $11 / 12 / 2002$ & GRSUNF & M & 11394 & 12.2 & 33.9 & $<0.025$ & $<0.022$ & $<0.027$ & $<0.0095$ & $0.10 \mathrm{U}$ & N/A & N/A \\
\hline BLK25.0 & $11 / 12 / 2002$ & GRSUNF & $\mathrm{F}$ & 11395 & 11.4 & 33.4 & $<0.023$ & $<0.02$ & $<0.025$ & $<0.0087$ & $0.09 \mathrm{U}$ & N/A & N/A \\
\hline BLK25.0 & $11 / 12 / 2002$ & GRSUNF & M & 11396 & 14.0 & 59.1 & $<0.014$ & $<0.012$ & $<0.016$ & $<0.0053$ & $0.06 \mathrm{U}$ & N/A & N/A \\
\hline BLK25.0 & $11 / 12 / 2002$ & GRSUNF & $\mathrm{M}$ & 11397 & 13.0 & 49.7 & $<0.017$ & $<0.015$ & $<0.019$ & $<0.0066$ & $0.07 \mathrm{U}$ & N/A & N/A \\
\hline BLK27.0 & $11 / 13 / 2002$ & GRSUNF & $\mathrm{M}$ & 11460 & 15.5 & 81.9 & $<0.014$ & $<0.012$ & $<0.015$ & $<0.0053$ & $0.06 \mathrm{U}$ & N/A & N/A \\
\hline
\end{tabular}




\begin{tabular}{|c|c|c|c|c|c|c|c|c|c|c|c|c|c|}
\hline Site & $\begin{array}{c}\text { Collection } \\
\text { Date }\end{array}$ & Species & Sex & $\begin{array}{l}\text { Tag } \\
\text { No. }\end{array}$ & $\begin{array}{c}\text { Length } \\
(\mathrm{cm})\end{array}$ & $\begin{array}{c}\text { Weight } \\
\text { (g) }\end{array}$ & $\begin{array}{l}\text { PCB } \\
1242^{\mathrm{a}} \\
\end{array}$ & $\begin{array}{l}\text { PCB } \\
1248 \\
\end{array}$ & $\begin{array}{l}\text { PCB } \\
1254 \\
\end{array}$ & $\begin{array}{l}\text { PCB } \\
1260^{a} \\
\end{array}$ & $\begin{array}{c}\text { Total } \\
\text { PCBs }^{\text {a,b }} \\
\end{array}$ & $\begin{array}{c}\text { Alpha } \\
\text { Chlordane }^{c}\end{array}$ & $\begin{array}{c}\text { Gamma } \\
\text { Chlordane }\end{array}$ \\
\hline BLK27.0 & $11 / 13 / 2002$ & GRSUNF & $\mathrm{F}$ & 11461 & 14.5 & 61.0 & $<0.013$ & $<0.012$ & $<0.014$ & $<0.005$ & $0.05 \mathrm{U}$ & N/A & $\mathrm{N} / \mathrm{A}$ \\
\hline BLK27.0 & $11 / 13 / 2002$ & GRSUNF & M & 11462 & 14.5 & 58.1 & $<0.013$ & $<0.011$ & $<0.014$ & $<0.005$ & $0.05 \mathrm{U}$ & N/A & $\mathrm{N} / \mathrm{A}$ \\
\hline BLK27.0 & $11 / 13 / 2002$ & GRSUNF & M & 11463 & 15.2 & 68.8 & $<0.012$ & $<0.01$ & $<0.013$ & $<0.0045$ & $0.05 \mathrm{U}$ & $\mathrm{N} / \mathrm{A}$ & $\mathrm{N} / \mathrm{A}$ \\
\hline BLK27.0 & $11 / 13 / 2002$ & GRSUNF & M & 11464 & 12.5 & 45.3 & $<0.018$ & $<0.016$ & $<0.02$ & $<0.0069$ & $0.07 \mathrm{U}$ & $\mathrm{N} / \mathrm{A}$ & $\mathrm{N} / \mathrm{A}$ \\
\hline BLK27.0 & $11 / 13 / 2002$ & GRSUNF & $\mathrm{F}$ & 11465 & 13.5 & 44.3 & $<0.019$ & $<0.017$ & $<0.021$ & $<0.0073$ & $0.08 \mathrm{U}$ & $\mathrm{N} / \mathrm{A}$ & $\mathrm{N} / \mathrm{A}$ \\
\hline BLK27.0 & $11 / 13 / 2002$ & GRSUNF & $\mathrm{F}$ & 11466 & 13.5 & 42.4 & $<0.017$ & $<0.015$ & $<0.019$ & $<0.0065$ & $0.07 \mathrm{U}$ & N/A & N/A \\
\hline BLK27.0 & $11 / 13 / 2002$ & GRSUNF & M & 11467 & 13.1 & 42.4 & $<0.021$ & $<0.018$ & $<0.023$ & $<0.0079$ & $0.08 \mathrm{U}$ & N/A & N/A \\
\hline BLK31.0 & $11 / 13 / 2002$ & GRSUNF & $\mathrm{F}$ & 11590 & 13.7 & 49.9 & $<0.016$ & $<0.014$ & $<0.018$ & $<0.006$ & $0.06 \mathrm{U}$ & $\mathrm{N} / \mathrm{A}$ & N/A \\
\hline BLK31.0 & $11 / 13 / 2002$ & GRSUNF & $\mathrm{F}$ & 11591 & 13.8 & 49.2 & $<0.015$ & $<0.014$ & $<0.017$ & $<0.0059$ & $0.06 \mathrm{U}$ & N/A & N/A \\
\hline BLK31.0 & $11 / 13 / 2002$ & GRSUNF & $\mathrm{F}$ & 11592 & 12.0 & 30.9 & $<0.027$ & $<0.024$ & $<0.03$ & $<0.01$ & $0.11 \mathrm{U}$ & N/A & N/A \\
\hline BLK31.0 & $11 / 13 / 2002$ & GRSUNF & M & 11593 & 16.5 & 85.9 & $<0.018$ & $<0.016$ & $<0.02$ & $<0.007$ & $0.07 \mathrm{U}$ & N/A & N/A \\
\hline BLK31.0 & $11 / 13 / 2002$ & GRSUNF & $\mathrm{F}$ & 11594 & 13.0 & 40.7 & $<0.02$ & $<0.017$ & $<0.022$ & $<0.0075$ & $0.08 \mathrm{U}$ & N/A & N/A \\
\hline BLK31.0 & $11 / 13 / 2002$ & GRSUNF & $\mathrm{M}$ & 11595 & 13.8 & 53.9 & $<0.016$ & $<0.014$ & $<0.018$ & $<0.0062$ & $0.06 \mathrm{U}$ & N/A & N/A \\
\hline BLK 31.0 & $11 / 13 / 2002$ & GRSUNF & $\mathrm{M}$ & 11596 & 11.1 & 22.7 & $<0.018$ & $<0.016$ & $<0.02$ & $<0.007$ & $0.07 \mathrm{U}$ & $\mathrm{N} / \mathrm{A}$ & $\mathrm{N} / \mathrm{A}$ \\
\hline BLK31.0 & $11 / 13 / 2002$ & GRSUNF & $\mathrm{M}$ & 11597 & 12.8 & 34.3 & $<0.021$ & $<0.019$ & $<0.024$ & $<0.0082$ & $0.09 \mathrm{U}$ & N/A & $\mathrm{N} / \mathrm{A}$ \\
\hline BCK0.2 & $10 / 28 / 2002$ & GRSUNF & $\mathrm{M}$ & 11560 & 11.5 & 26.7 & 0.19 & $<0.012$ & 0.10 & $<0.0054$ & 0.29 & $\mathrm{~N} / \mathrm{A}$ & $\mathrm{N} / \mathrm{A}$ \\
\hline BCK0.2 & $10 / 28 / 2002$ & GRSUNF & $\mathrm{M}$ & 11561 & 12.1 & 34.6 & 0.25 & $<0.0092$ & 0.16 & $<0.004$ & 0.41 & N/A & N/A \\
\hline BCK0.2 & $10 / 28 / 2002$ & GRSUNF & $\mathrm{M}$ & 11562 & 12.2 & 31.7 & 0.22 & $<0.01$ & 0.13 & $<0.0044$ & 0.35 & N/A & N/A \\
\hline BCK0.2 & $10 / 28 / 2002$ & GRSUNF & M & 11563 & 12.3 & 34.0 & 0.15 & $<0.01$ & 0.17 & $<0.0043$ & 0.32 & N/A & N/A \\
\hline BCK0.2 & $10 / 28 / 2002$ & GRSUNF & $\mathrm{F}$ & 11564 & 11.2 & 29.2 & 0.33 & $<0.011$ & 0.21 & $<0.0048$ & 0.54 & N/A & N/A \\
\hline BCK0.2 & $10 / 28 / 2002$ & GRSUNF & M & 11565 & 10.0 & 18.7 & 0.18 & $<0.023$ & 0.23 & $<0.0099$ & 0.41 & N/A & N/A \\
\hline BCK0.2 & $10 / 28 / 2002$ & GRSUNF & $\mathrm{M}$ & 11566 & 9.9 & 19.5 & 0.27 & $<0.017$ & 0.15 & $<0.0075$ & 0.42 & N/A & N/A \\
\hline BCK0.2 & $10 / 28 / 2002$ & GRSUNF & $\mathrm{M}$ & 11567 & 12.4 & 38.1 & 0.26 & $<0.017$ & 0.15 & $<0.0074$ & 0.41 & N/A & N/A \\
\hline ICK0.2 & $11 / 12 / 2002$ & CHNCAT & $\mathrm{F}$ & 11490 & 36.5 & 400.6 & 0.054 & $<0.0054$ & $<0.0068$ & 0.052 & 0.11 & $0.0130 \mathrm{P}$ & 0.0110 \\
\hline ICK0.2 & $11 / 12 / 2002$ & CHNCAT & M & 11491 & 37.0 & 370.5 & $0.015 \mathrm{~J}$ & $<0.0055$ & $<0.0069$ & 0.042 & 0.06 & $0.0032 \mathrm{P}$ & $<0.0004$ \\
\hline ICK 0.2 & $11 / 12 / 2002$ & CHNCAT & M & 11492 & 31.7 & 257.0 & 0.028 & $<0.0056$ & $<0.007$ & 0.045 & 0.07 & $0.0110 \mathrm{P}$ & $0.0110 \mathrm{P}$ \\
\hline ICK 0.2 & $11 / 12 / 2002$ & CHNCAT & $\mathrm{F}$ & 11493 & 38.3 & 398.4 & $0.023 \mathrm{~J}$ & $<0.0055$ & $<0.0069$ & 0.057 & 0.08 & $0.0110 \mathrm{P}$ & 0.0088 \\
\hline ICK0.2 & $11 / 12 / 2002$ & CHNCAT & $\mathrm{F}$ & 11494 & 41.9 & 619.5 & 0.025 & $<0.0055$ & $<0.0069$ & 0.047 & 0.07 & $0.0100 \mathrm{P}$ & $0.0130 \mathrm{P}$ \\
\hline ICK0.2 & $11 / 12 / 2002$ & CHNCAT & $\mathrm{F}$ & 11495 & 39.9 & 558.1 & 0.034 & $<0.0055$ & $<0.0069$ & 0.054 & 0.09 & $0.0190 \mathrm{P}$ & $0.0210 \mathrm{P}$ \\
\hline ICK0.2 & $11 / 14 / 2002$ & CHNCAT & $\mathrm{M}$ & 11528 & 37.7 & 428.9 & $0.022 \mathrm{~J}$ & $<0.0055$ & $<0.0069$ & 0.033 & 0.06 & $0.0130 \mathrm{P}$ & 0.0110 \\
\hline ICK0.2 & $11 / 14 / 2002$ & CHNCAT & $\mathrm{M}$ & 11529 & 37.3 & 357.2 & 0.066 & $<0.0054$ & $<0.0068$ & 0.033 & 0.10 & $0.0070 \mathrm{P}$ & $0.0028 \mathrm{P}$ \\
\hline BLK27.0 & $11 / 13 / 2002$ & CHNCAT & $\mathrm{F}$ & 11470 & 44.5 & 678.3 & 0.26 & $<0.0056$ & $<0.0065$ & 0.21 & 0.47 & $0.0280 \mathrm{P}$ & $0.0250 \mathrm{P}$ \\
\hline BLK27.0 & $11 / 13 / 2002$ & CHNCAT & M & 11471 & 44.5 & 651.2 & $<0.0069$ & $<0.0053$ & $<0.0063$ & 0.11 & 0.11 & $0.0019 \mathrm{P}$ & $<0.0003$ \\
\hline BLK27.0 & $11 / 13 / 2002$ & CHNCAT & M & 11472 & 46.6 & 875.3 & 0.05 & $<0.0053$ & $<0.0063$ & 0.15 & 0.20 & $0.0140 \mathrm{P}$ & $<0.0017$ \\
\hline BLK27.0 & $11 / 13 / 2002$ & CHNCAT & $\mathrm{F}$ & 11473 & 48.3 & 777.0 & 0.046 & $<0.0053$ & $<0.0063$ & 0.23 & 0.28 & $0.0210 \mathrm{P}$ & $<0.0017$ \\
\hline
\end{tabular}




\begin{tabular}{|c|c|c|c|c|c|c|c|c|c|c|c|c|c|}
\hline Site & $\begin{array}{c}\text { Collection } \\
\text { Date }\end{array}$ & Species & Sex & $\begin{array}{l}\text { Tag } \\
\text { No. }\end{array}$ & $\begin{array}{c}\text { Length } \\
\text { (cm) }\end{array}$ & $\begin{array}{c}\text { Weight } \\
\text { (g) }\end{array}$ & $\begin{array}{l}\text { PCB } \\
1242^{\mathrm{a}} \\
\end{array}$ & $\begin{array}{l}\text { PCB } \\
1248 \\
\end{array}$ & $\begin{array}{l}\text { PCB } \\
1254 \\
\end{array}$ & $\begin{array}{r}\text { PCB } \\
1260^{a} \\
\end{array}$ & $\begin{array}{c}\text { Total } \\
\text { PCBs }^{\mathrm{a}, \mathrm{b}}\end{array}$ & $\begin{array}{c}\text { Alpha } \\
\text { Chlordane }\end{array}$ & $\begin{array}{c}\text { Gamma } \\
\text { Chlordane }\end{array}$ \\
\hline BLK27.0 & $11 / 13 / 2002$ & CHNCAT & $\mathrm{M}$ & 11474 & 51.6 & 1107.9 & $<0.0069$ & $<0.0054$ & $<0.0063$ & 0.16 & 0.16 & $0.0049 \mathrm{P}$ & $<0.0004$ \\
\hline BLK27.0 & $11 / 13 / 2002$ & CHNCAT & M & 11475 & 45.2 & 740.1 & 0.026 & $<0.0054$ & $<0.0063$ & 0.22 & 0.25 & $0.0070 \mathrm{P}$ & $<0.0004$ \\
\hline BLK27.0 & $11 / 13 / 2002$ & CHNCAT & M & 11476 & 50.7 & 1164.7 & $<0.0071$ & $<0.0055$ & $<0.0065$ & 0.14 & 0.14 & $0.0160 \mathrm{P}$ & $<0.0007$ \\
\hline BLK27.0 & $11 / 13 / 2002$ & CHNCAT & $\mathrm{F}$ & 11477 & 41.3 & 639.2 & 0.15 & $<0.0055$ & $<0.0064$ & 0.2 & 0.35 & $0.0230 \mathrm{P}$ & $<0.0018$ \\
\hline BLK31.0 & $11 / 13 / 2002$ & CHNCAT & $\mathrm{M}$ & 11510 & 53.1 & 1254.9 & $<0.0063$ & $<0.0049$ & $<0.0058$ & 0.06 & 0.06 & $0.0023 \mathrm{P}$ & $<0.0003$ \\
\hline BLK31.0 & $11 / 13 / 2002$ & CHNCAT & $\mathrm{F}$ & 11511 & 34.6 & 349.7 & $<0.007$ & $<0.0055$ & $<0.0064$ & $0.024 \mathrm{~J}$ & $0.02 \mathrm{~J}$ & $0.0044 \mathrm{P}$ & $<0.0004$ \\
\hline BLK31.0 & $11 / 13 / 2002$ & CHNCAT & M & 11512 & 45.2 & 743.2 & $<0.0066$ & $<0.0052$ & $<0.0061$ & 0.033 & 0.03 & $0.0051 \mathrm{P}$ & $<0.0003$ \\
\hline BLK31.0 & $11 / 13 / 2002$ & CHNCAT & M & 11513 & 52.7 & 1200.6 & $<0.0068$ & $<0.0053$ & $<0.0062$ & 0.036 & 0.04 & $0.0019 \mathrm{P}$ & $<0.0003$ \\
\hline BLK31.0 & $11 / 13 / 2002$ & CHNCAT & $\mathrm{F}$ & 11514 & 41.7 & 606.3 & $<0.0067$ & $<0.0052$ & $<0.0061$ & 0.023 & 0.02 & $0.0016 \mathrm{JP}$ & $<0.0003$ \\
\hline BLK31.0 & $11 / 13 / 2002$ & CHNCAT & M & 11515 & 52.0 & 1126.6 & $<0.007$ & $<0.0054$ & $<0.0064$ & 0.045 & 0.05 & $0.0019 \mathrm{P}$ & $<0.0004$ \\
\hline BLK31.0 & $11 / 13 / 2002$ & CHNCAT & M & 11516 & 39.1 & 447.4 & $<0.007$ & $<0.0055$ & $<0.0064$ & $0.024 \mathrm{~J}$ & $0.02 \mathrm{~J}$ & $0.0017 \mathrm{JP}$ & $<0.0004$ \\
\hline BLK31.0 & $11 / 13 / 2002$ & CHNCAT & $\mathrm{M}$ & 11517 & 34.4 & 293.8 & $<0.0071$ & $<0.0055$ & $<0.0065$ & 0.025 & 0.03 & $0.0042 \mathrm{P}$ & 0.0031 \\
\hline BLK25.0 & $11 / 14 / 2002$ & CHNCAT & $\mathrm{F}$ & 11525 & 46.5 & 761.7 & $0.015 \mathrm{~J}$ & $<0.0054$ & $<0.0068$ & 0.048 & 0.06 & 0.0024 & $<0.0003$ \\
\hline BCK0.2 & $10 / 28 / 2002$ & CHNCAT & $\mathrm{F}$ & 11569 & 50.3 & 763.5 & 0.019 & $<0.0057$ & $<0.0072$ & 0.15 & 0.17 & $0.0110 \mathrm{P}$ & $<0.0007$ \\
\hline
\end{tabular}

${ }^{\mathrm{a}} \mathrm{J}=$ estimated. < = less than the method's lower limit.

${ }^{\mathrm{b}} \mathrm{U}=$ undetected. Less than the contract required quantitation limit.

${ }^{\mathrm{c}} \mathrm{P}=$ second column confirmation $>25 \%$ different.

${ }^{\mathrm{d}}$ Indeterminate. 
Table A-2. Composite sample data for Asiatic clams (Corbicula fluminea) collected from sites on Indian Creek (ICK) and the Blue River (BLK) near the Kansas City Plant, November 2002. < = Lower limit. U = Below quantitation limit.

\begin{tabular}{|c|c|c|c|c|c|c|c|c|c|c|c|c|}
\hline \multirow{2}{*}{\begin{tabular}{|l} 
Site \\
Date collected \\
Sample \# \\
\end{tabular}} & \multicolumn{2}{|c|}{$\begin{array}{c}\text { ICK0.2 } \\
11 / 14 / 2002\end{array}$} & \multicolumn{2}{|c|}{$\begin{array}{c}\text { ICK1.0 } \\
\text { 11/13/2002 }\end{array}$} & \multicolumn{2}{|c|}{$\begin{array}{c}\text { ICK3.0 } \\
11 / 14 / 2002\end{array}$} & \multicolumn{2}{|c|}{$\begin{array}{c}\text { BLK25.0 } \\
\text { 11/14/2002 }\end{array}$} & \multicolumn{2}{|c|}{$\begin{array}{c}\text { BLK27.0 } \\
\text { 11/13/2002 }\end{array}$} & \multicolumn{2}{|c|}{$\begin{array}{c}\text { BLK31.0 } \\
\text { 11/13/2002 }\end{array}$} \\
\hline & 11509A & 11509B & 11459A & 11459B & $11527 \mathrm{~A}$ & 11527B & $11524 \mathrm{~A}$ & 11524B & $11469 A$ & 11469B & 11519A & 11519B \\
\hline INDIVIDUAL & 2.77 & 2.53 & 2.74 & 2.47 & 2.83 & 1.75 & 2.82 & 2.57 & 2.70 & 2.55 & 2.86 & 2.53 \\
\hline WHOLE & 3.80 & 4.10 & 4.13 & 3.93 & 2.68 & 1.43 & 3.99 & 3.87 & 4.10 & 4.03 & 3.90 & 4.12 \\
\hline CLAM & 2.98 & 3.14 & 2.80 & 3.21 & 3.08 & 1.01 & 2.95 & 2.98 & 3.38 & 3.17 & 2.72 & 3.09 \\
\hline WTS (g) & 2.42 & 2.35 & 2.43 & 2.32 & 2.49 & 0.74 & 2.41 & 2.35 & 2.33 & 2.32 & 2.50 & 2.20 \\
\hline & 3.66 & 3.22 & 3.28 & 3.21 & 2.63 & 0.79 & 3.27 & 3.33 & 3.34 & 3.39 & 3.64 & 3.23 \\
\hline & 5.48 & 5.29 & 5.39 & 5.65 & 4.25 & 0.83 & 6.12 & 5.91 & 5.57 & 5.32 & 5.47 & 5.98 \\
\hline & 2.20 & 2.18 & 1.98 & 2.09 & 2.02 & 0.71 & 2.23 & 2.56 & 2.25 & 2.18 & 2.08 & 2.00 \\
\hline & 3.03 & 2.47 & 2.65 & 2.31 & 2.11 & 1.05 & 2.67 & 2.32 & 2.95 & 2.54 & 2.44 & 2.71 \\
\hline & 3.32 & 3.45 & 3.78 & 3.56 & & 0.78 & 3.62 & 3.79 & 3.82 & 3.59 & 3.78 & 3.73 \\
\hline & 3.04 & 3.16 & 2.92 & 2.81 & & 0.71 & 3.14 & 3.04 & 3.10 & 3.01 & 2.88 & 2.82 \\
\hline & 4.34 & 4.57 & 4.47 & 4.52 & & 0.70 & 4.23 & 4.38 & 4.52 & 4.23 & 4.30 & 4.39 \\
\hline & 4.17 & 3.46 & 4.10 & 3.70 & & 0.64 & 4.04 & 3.69 & 3.96 & 4.12 & 3.94 & 3.65 \\
\hline & 4.59 & 6.29 & 5.02 & 4.33 & & 0.67 & 5.23 & 4.59 & 4.47 & 4.38 & 5.82 & 4.06 \\
\hline & 6.57 & 4.97 & 5.03 & 4.90 & & 0.64 & 4.85 & 4.87 & 4.85 & 4.87 & 2.59 & 3.89 \\
\hline & 5.75 & 5.20 & 5.13 & 5.20 & & 0.80 & 5.39 & 5.20 & 5.39 & 5.19 & 3.00 & 3.35 \\
\hline & 3.22 & 3.70 & 3.53 & 3.89 & & 0.69 & 4.28 & 4.16 & 3.43 & 3.72 & 2.63 & 3.54 \\
\hline & 4.74 & 5.61 & 4.81 & 5.86 & & 0.63 & 4.78 & 5.86 & 4.74 & 4.23 & 2.36 & 2.95 \\
\hline & 3.48 & 4.58 & 3.49 & 5.12 & & 0.63 & 4.32 & 4.32 & 4.19 & 4.53 & 2.61 & 2.40 \\
\hline & 2.89 & 3.13 & 2.98 & 3.15 & & 0.62 & 4.18 & 3.94 & 3.38 & 3.25 & 2.26 & 2.17 \\
\hline & 3.35 & 4.76 & 6.30 & 4.86 & & 0.61 & 4.30 & 4.49 & 4.43 & 4.57 & 2.58 & 2.39 \\
\hline Sum & 75.80 & 78.16 & 76.96 & 77.09 & 22.09 & 16.43 & 78.82 & 78.22 & 76.90 & 75.19 & 64.36 & 65.20 \\
\hline Ave Indiv. Wt. & 3.79 & 3.91 & 3.85 & 3.85 & 2.76 & 0.82 & 3.94 & 3.91 & 3.85 & 3.76 & 3.22 & 3.26 \\
\hline Total soft tissue wt & 22.58 & 21.08 & 21.59 & 23.22 & 5.08 & 3.17 & 20.16 & 20.61 & 22.11 & 21.60 & 18.38 & 18.95 \\
\hline \% Lipid & 0.73 & 0.70 & 0.96 & 0.88 & 1.75 & 2.08 & 1.20 & 1.28 & 1.01 & 1.22 & 1.11 & 1.21 \\
\hline PCB-1242 & $<0.0058$ & $<0.0062$ & $<0.061$ & $<0.056$ & $<0.029$ & $<0.043$ & 0.047 & 0.041 & 0.028 & 0.024 & $<0.071$ & $<0.068$ \\
\hline PCB-1254 & $<0.0064$ & $<0.0069$ & $<0.068$ & $<0.062$ & $<0.032$ & $<0.048$ & 0.035 & 0.028 & 0.038 & 0.037 & $0.022 \mathrm{~J}$ & $0.029 \mathrm{~J}$ \\
\hline Total PCB & $0.023 \mathrm{U}$ & $0.024 \mathrm{U}$ & $0.024 \mathrm{U}$ & $0.022 \mathrm{U}$ & $0.11 \mathrm{U}$ & $0.17 \mathrm{U}$ & 0.082 & 0.069 & 0.066 & 0.061 & $0.022 \mathrm{~J}$ & $0.029 \mathrm{~J}$ \\
\hline
\end{tabular}



APPENDIX B

QUALITY ASSURANCE SUMMARY 

Recoveries of PCB standards (0.5 ppm Aroclor 1254 ) spiked into uncontaminated sunfish (homogenized composites of bluegill sunfish from Melton Hill Reservoir, Anderson Co., TN) were good, averaging $93 \pm 9 \%$ (mean $\pm \mathrm{SD}, \mathrm{N}=6$ ). The mean recoveries of surrogate standards spiked into each sample were $80 \pm 15 \%$ and $110 \pm 20 \%(\mathrm{~N}=125)$ for tetrachloro-m-xylene and decachlorobiphenyl, respectively. These two compounds would be expected to bracket the chromatographic range of Aroclor $1242-1260$ in the analysis. Recoveries of these surrogates compared well with results of PCB spike recoveries. Analysis of the reference fish (the same fish used for spike recoveries) found traces of Aroclor $1260(0.038 \pm 0.024, \mathrm{~N}=5)$, but all other PCB mixtures were below the detection limit $(<0.010 \mu \mathrm{g} / \mathrm{g})$.

Precision of the analysis of matrix spike samples was excellent, with an average relative percent difference (RPD) between spiked pairs of 3.4\%. The RPD for actual sample duplicates was also very good, at $13 \%$ (Table A-1). For sunfish filets the duplicates are a subsample from the same filet, but are not exact replicates of the same part of the filet (unlike catfish, which are homogenized before subsample preparation). This explains some of the variation observed between duplicates. Also, very low values very close to or below the quantitation limit of the analysis would expect to have higher percent differences in values. The mean absolute difference between duplicate pairs was $0.05 \mu \mathrm{g} / \mathrm{g}$ for total PCBs, $0.004 \mu \mathrm{g} / \mathrm{g}$ for alpha chlordane, and $0.009 \mu \mathrm{g} / \mathrm{g}$ for gamma chlordane.

Qualitative identification of weathered PCB mixtures at concentrations near analytical detection limits is problematic, especially if other chlorinated compounds (such as chlordane) are present. Thus, the distinction between Aroclor 1242 and 1248, or 1254 and 1260, is to some degree a subjective judgment on the part of the analyst. Distinguishing between more disparate mixtures, such as Aroclor 1242 and 1254/1260, as was the case in these samples, is a clearer distinction. There is a high degree of confidence that the KCP samples have PCBs originating from two distinct primary source mixtures.

Chlordane analyses were characterized by consistent differences in quantification on the two analytical columns used in the procedure. Apparently, the alpha chlordane had an interference or some unknown matrix effect that caused a retention time shift and a higher calculated result on the Stx-CLPesticides column. This behavior was observed in matrix spike samples as well as routine fish samples. Therefore, alpha chlordane results were flagged with a "P" qualifier which indicate confirmation but not quantitative agreement between the two columns. 
Table B-1. Results of blind duplicate samples analyzed for PCBs and Chordane.

\begin{tabular}{|c|c|c|c|c|c|c|c|}
\hline $\begin{array}{c}\text { Duplicate } \\
\text { pairs }\end{array}$ & $\begin{array}{l}\text { PCB- } \\
1242 \\
\end{array}$ & $\begin{array}{l}\text { PCB- } \\
1248 \\
\end{array}$ & $\begin{array}{l}\text { PCB- } \\
1254 \\
\end{array}$ & $\begin{array}{l}\text { PCB- } \\
1260 \\
\end{array}$ & $\begin{array}{l}\text { PCB } \\
\text { SUM } \\
\end{array}$ & $\begin{array}{l}\text { Alpha } \\
\text { Chlordane } \\
\end{array}$ & $\begin{array}{l}\text { Gamma } \\
\text { Chlordane }\end{array}$ \\
\hline 11520 & 0.061 & $<0.011$ & $<0.014$ & 0.052 & 0.113 & & \\
\hline 11497 & 0.062 & $<0.012$ & $<0.015$ & 0.065 & 0.127 & & \\
\hline 11567 & 0.260 & $<0.017$ & 0.150 & $<0.007$ & 0.410 & & \\
\hline 11568 & 0.440 & $<0.017$ & 0.240 & $<0.007$ & 0.680 & & \\
\hline 11392 & 0.064 & $<0.010$ & $<0.012$ & J 0.026 & 0.090 & & \\
\hline 11398 & $<0.011$ & $<0.010$ & $<0.012$ & $<0.004$ & U 0.044 & & \\
\hline 11450 & $<0.015$ & $<0.013$ & $<0.016$ & $\mathrm{~J} 0.036$ & $\mathrm{~J} 0.036$ & & \\
\hline 11458 & $<0.017$ & $<0.015$ & $<0.019$ & $<0.007$ & U 0.069 & & \\
\hline 11460 & $<0.014$ & $<0.012$ & $<0.015$ & $<0.005$ & U 0.055 & & \\
\hline 11468 & $<0.015$ & $<0.013$ & $<0.017$ & $<0.006$ & U 0.060 & & \\
\hline 11477 & 0.150 & $<0.006$ & $<0.006$ & 0.200 & 0.350 & P 0.023 & $<0.002$ \\
\hline 11478 & 0.210 & $<0.005$ & 0.280 & $<0.002$ & 0.490 & P 0.033 & 0.029 \\
\hline 11494 & 0.025 & $<0.006$ & $<0.007$ & 0.047 & 0.072 & P 0.010 & 0.013 \\
\hline 11479 & 0.024 & $<0.005$ & $<0.006$ & 0.055 & 0.079 & P 0.011 & 0.012 \\
\hline 11510 & $<0.006$ & $<0.005$ & $<0.006$ & 0.060 & 0.060 & P 0.002 & $<0.000$ \\
\hline 11518 & $<0.007$ & $<0.005$ & $<0.006$ & 0.058 & 0.058 & P 0.002 & $<0.000$ \\
\hline \multicolumn{5}{|c|}{ Mean Difference: } & 0.05 & 0.004 & 0.009 \\
\hline
\end{tabular}

Note:

Arochlor-1016, -1221, and -1232 were analyzed for, but undetected.

$<=$ Lower Limit.

$\mathrm{U}=$ Undetected at contract required quantitation limit.

$\mathrm{J}=$ Estimated value.

$\mathrm{P}=$ Greater than $25 \%$ difference between columns. 


\section{INTERNAL DISTRIBUTION}

1. S. G. Hildebrand

2. J. M. Loar

3-42. M. J. Peterson

43. M. J. Sale

44. G. R. Southworth
44-46. ESD Library

47. ORNL Central Research Library

48. ORNL Laboratory Records RC

49. ORNL Laboratory Records OSTI

\section{EXTERNAL DISTRIBUTION}

50. Michael Stites, Honeywell FM\&T, D/SE1, OD48, 2000 East 95th Street Kansas City, MO 64141-6159 